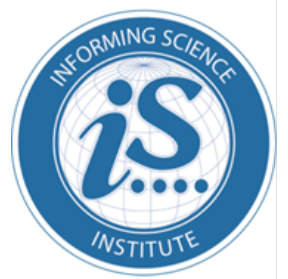

Proceedings of the Informing Science + Information Technology Education Conference

An Official Publication

of the Informing Science Institute

InformingScience.org

InformingScience.org/Publications

Online July 7-8, 2020

\title{
DEVELOPING AN IT COURSE FOR EMERGING TECHNOLOGIES USING A FRAMEWORK - AN EXAMPLE OF AN IOT COURSE V1.0
}

\begin{tabular}{|c|c|c|}
\hline Norman van Wyk & $\begin{array}{l}\text { Noroff University College, Kristian- } \\
\text { sand, Norway, and } \\
\text { University of Cape Town, Cape Town, } \\
\text { South Africa }\end{array}$ & $\begin{array}{l}\text { norman.van.wyk@,noroff.no } \\
\text { vWYNOR002@myuct.ac.za }\end{array}$ \\
\hline Kevin Johnston* & $\begin{array}{l}\text { University of Cape Town, Cape Town, } \\
\text { South Africa }\end{array}$ & kevin.johnston@uct.ac.za \\
\hline Klaus Möller & $\begin{array}{l}\text { Pforzheim University, Pforzheim, } \\
\text { Germany }\end{array}$ & klaus.moeller@hs-pforzheim.de \\
\hline Florian Haas & $\begin{array}{l}\text { Pforzheim University, Pforzheim, } \\
\text { Germany }\end{array}$ & Florian.haas@hs-pforzheim.de \\
\hline
\end{tabular}

\section{ABSTRACT}

Aim/Purpose Academics are often requested to create and teach courses for emerging technologies with perhaps no experience or guidance on how to do so.

Background

A Framework to develop IT courses for emerging technologies was created and tested to assist academics; the framework was then tested by developing an IoT course.

Methodology

A literature review was conducted to discover theories, models and methods that could be used in the creation of IT courses, followed by interviews with academics who had created many courses. The interviews were analysed using a thematic analysis process, and a Course Development Framework was created. The framework was tested by using it to build and deliver an IoT course.

Contribution The Framework could be used to support academics who have to create and develop IT courses for emerging technologies.

Accepted by executive review by Editor Michael Jones | Received: December 16, 2019 | Revised: January 29, 2020 | Accepted: February 5, 2020.

Cite as: van Wyk, N., Johnston, K., Möller, K., \& Haas, F. (2020). Developing an IT course for emerging technologies using a framework - An example of an IoT course V1.0. In M. Jones (Ed.), Proceedings of InSITE 2020: Informing Science and Information Technology Education Conference, 15-45. Informing Science Institute. https://doi.org/10.28945/4521

(CC BY-NC 4.0) This article is licensed to you under a Creative Commons Attribution-NonCommercial 4.0 International License. When you copy and redistribute this paper in full or in part, you need to provide proper attribution to it to ensure that others can later locate this work (and to ensure that others do not accuse you of plagiarism). You may (and we encourage you to) adapt, remix, transform, and build upon the material for any non-commercial purposes. This license does not permit you to use this material for commercial purposes. 
Findings By combining a learning theory such as constructivism, the ADDIE Instructional design model, ARCS-V Motivational model, and Bloom's Taxonomy, a Course Development Framework was constructed, which could be used to support academics who have to create courses for emerging technologies.

Recommendations The Course Development Framework could be used to develop other IT for Practitioners courses including online courses.

Recommendations Future research could be conducted in the effectiveness of using the Course for Researchers Development Framework to develop other courses including online courses.

Impact on Society Support academics to develop better IT courses for emerging technologies.

Future Research Research in the field of Brain Compatible Learning Principles and combining or using it with the Framework could provide further insights into advancements in course design and development.

Keywords instructional design, framework, motivation, course development, educational technology, emerging technology

\section{INTRODUCTION}

Learners today expect exciting and engaging activities with diverse instructional styles, but unfortunately, many academics have been slow to adopt changes in learning approaches (Arghode et al., 2017). Information technology (IT) is continually evolving and new IT is emerging; this requires academics to develop courses for these emerging technologies, many of which are required to be taught online (Horvitz et al., 2015). Consequently, developing courses for emerging technologies presents new challenges for academics. Researchers have stressed the need for diverse didactic principles for learning, instruction design and learning philosophies (Arghode et al., 2017). For this reason, there is a current need for a framework that could guide academics to develop courses, especially courses in emerging technologies (Panetta, 2018). Van Wyk (2019) developed a Framework for developing online courses, and this paper is based on and builds on Van Wyk's work.

Academics are increasingly likely to be required to develop courses for emerging technologies such as the Internet of Things (IoT), Virtual Reality (VR), Digital Twins, and Smart Dust (amongst others) for learners who prefer to use mobile web-enabled devices in the classroom (Johnston, 2016), and may also prefer using online learning (Panetta, 2018).

From a general institutional perspective, developing a new course requires an academic to consider not only the content required, but also a multitude of additional factors across a range of disciplines (McCaffrey, 2017). For example, to develop an IoT course, one would need to consider the IoT content itself, as well as possibly utilising a framework to build the course. For this reason, the primary aim of this empirical research was to create a general-purpose Course Development Framework that could aid academics in developing emerging technology courses. Within the scope of this research study, IoT was used as a test case of an emerging technology, and an IoT course was developed and presented in Germany in late 2019.

Io'T could, on the one side, be seen as a cross functional development. On the other side, each discipline in a corporation has to consider the potential of applications of IoT in depth within its own environment. And hence there is a high relevance for the education of future managers, for example, in manufacturing or purchasing and logistics. In logistics, IoT will have huge implications for the business. Macaulay et al. (2015) predicted that we would move from 15 billion connected devices in 2015 to some 50 billion by 2020. The resulting visibility will transform our business processes, in particular in logistics. Consequently IoT will increase supply chain visibility and agility as well as its resilience to un-precedented events. A literature review on the potential for added value of IoT in Supply Chain Management shows that the applications are still in an early stage (Ben-Daya et al., 2017). But with 
the promising areas in mind, academics must reflect today how they will transfer the uprising potential of IoT into the education environment. So, the Course Development Framework could also be used for other courses for emerging technologies, such as Augmented Reality, Mixed Reality, and Virtual Reality, as well as for developing online courses.

To begin the research, a review of the literature was conducted (van Wyk, 2019), this was followed by interviewing academics who had developed several courses (including online courses) at universities in Europe and Africa. Responding academics were regarded as experts in the field of IT education due to the nature of their work, experience, research, and positions in academia. Data from the literature review and the interviews was gathered and analysed and a Course Development Framework developed. The Framework was then presented as a proof of concept to several of the academics interviewed and refined based on their comments and suggestions. Finally, a course outline for an emerging technology, IoT in this case, was developed using the Framework. The course was presented at a university in Germany, and feedback was obtained from the students who completed the course.

There were concerns over personal and organisational information of the respondents being obtained and kept.

To address the ethical and privacy concerns of the responding academics and students, all identifiable information of the respondents (and higher educational institutions in which they were operating) has been removed, and respondents have been given pseudonyms.

\section{LITERATURE REVIEW}

A systematic literature review process taken from Brereton et al. (2007) was followed. Three stages as outlined by Brereton et al. (2007) of planning the literature review, conducting the literature review, and finally validating the literature review were followed. Literature was sourced mainly from Google Scholar and the Educational Resources Information Center (ERIC). Only papers published in English were included; all other languages were excluded. Furthermore, the literature search focused on results from the last five years, 2015-2019. Published and peer-reviewed journals were primarily used, and, where necessary, books and relevant websites were cited. Older references were used where appropriate to describe research based on prior research and findings such as Keller (2010). The literature review discusses learning theories, instructional design methods, and motivational design models that could be used to develop a Course Development Framework for emerging technologies. The literature review has the following main themes: learning theories, course development, design models, Bloom's taxonomy, and the IoT course request.

\section{LEARNING THEORIES}

Literature suggests that academics could benefit from research and support in the form of best practices in instructional design and student learning for creating new courses (Horvitz et al., 2015). Kizilcec et al. (2017) stated that student focusing research and best practices regarding student interactions would be welcome additions to instructional practices, especially if they are easy to apply.

In the twenty-first century the way academics address learning depends a lot on their experience, but additionally, and perhaps more importantly, academics will need to have a shift in perspective of learning as this type of learning is different from the learning in the more structured learning environments of the classroom (Yilmaz \& Cagiltay, 2016). The question of how learning takes place in a human being is a fundamental question in instruction and teaching (Illeris, 2018). Developed from learning psychology with additional influences such as pedagogical, sociological and medical research mainly in the form of cognitive and brain research has led to the development of learning theories (Illeris, 2018).

The literature review discussed learning theories and models that could be used to develop a Course Development Framework specifically for emerging technologies. Learning theory is a vast subject 
that has many different aspects such as neuroscience, psychology, and education (Juvova et al., 2015). Fundamental learning theories that are used within a broad spectrum of course material include cognitivism, connectivism, behaviourism and constructivism as shown in Figure 1.

\section{learning theories}

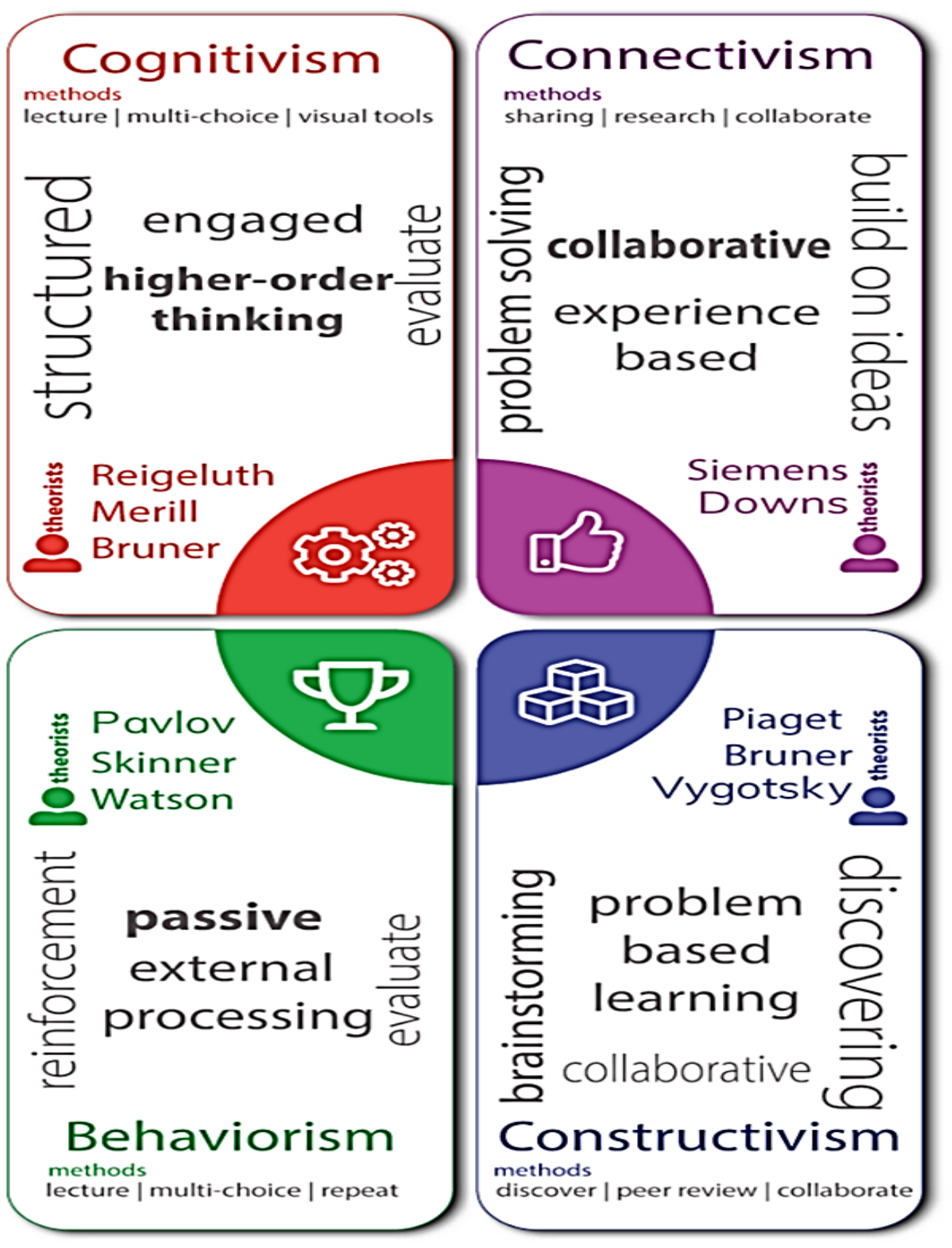

Figure 1. Popular learning theories (Davis, 2019). 
The literature review identified learning theories that could be used in the development of a Course Development Framework by looking at key elements of the learning theories that would prove useful for a course on emerging technologies such as IoT.

Learning theories outline how a student learns and acquires knowledge, retains knowledge, and recalls the knowledge by describing some general principles (Sahin \& Dogantay, 2018). Reflecting on the studies regarding learning theories, the paper by Arghode et al. (2017) states, "Learning theories deserve more attention in an online learning environment. The study of learning theories combined with an in-depth analysis of psychological and human resource literature will enable researchers to delve deeply into the subject. More qualitative studies are needed to explore further how an instructor's ability to utilize theoretical principles to improve instruction can make a difference in learning" (p. 604).

This led to the research question RQ1: Which learning theories could be useful as a basis to construct a framework for developing courses on emerging technologies?

\section{Behaviourism}

The behaviourism theory concentrates on measurable and observable behaviour or actions and on the importance of the consequences that follow the behavior or action (Saari, 2019). Behaviourism evolved from a positivist worldview related to cause and effect. Behaviourism ignores that which cannot be observed, thus it ignores the internal knowledge, previous knowledge, or mental process in determining the knowledge (Yarbrough, 2018). In education, behaviourism examines how students behave while learning. More specifically, behaviourism focuses on observing how students respond to certain stimuli that, when repeated, can be evaluated, quantified, and eventually controlled for each individual (Yarbrough, 2018). Consequently, the behaviourism theory establishes the theory as an idea that the learning behavior can be controlled by establishing consequences that will guide the behavior of the learner by providing negative or positive feedback as a response (Saari, 2019). The learning can then only be successful when students connect required responses with desired outcomes through conditioning (Arghode et al., 2017).

The behaviourism theory has established a very rigid and structured approach (Meier, 2016; Yarbrough, 2018). The idea is that by rewarding correct responses to solving a problem or answering a question correctly and punishing an incorrect answer by giving a negative response, the student will learn the correct behavior. Behaviourism does not take into account the mental processing by the learners but instead focuses solely on observable behavior (Robinson, 2018). Behaviourism teaches by enforcement and reinforcement of pre-conceived and designed outcomes (Saari, 2019). Behaviourism theory is often used in linguistic learning programs and training of animals (Meier, 2016; Saari, 2019).

Behaviourism started to show limitations when it could not explain many social behaviours, and this limitation gave rise to the Cognitivism theory (Harasim, 2017). Behaviourism could be used where the learning material could be developed so that it emphasizes a response conditioning approach.

Behaviourism theory could be appropriate when designing courses as it encourages the development of:

1.) Measurable and observable learning outcomes (Yan, 2017).

2.) Using rewards and feedback to improve performance (Arghode et al., 2017).

3.) To guide students to master predictable skills (Arghode et al., 2017).

\section{Connectivism}

The connectivism theory is described as learning in the information or digital age where learning knowledge is distributed across networks where connections and connectedness inform learning, 
based on the future not the past (Kizito, 2016). Students find meaning and make connections between data, ideas, and concepts as a crucial part of the learning experience (Reese, 2015). The clustering (gathering of information) of the nodes allows the students to share ideas, interact, and experience learning together (Goldie, 2016).

Technological advancements have occurred rapidly and traditional learning theories like behaviourism, have struggled to keep up with emerging technologies (Yumurtaci, 2017). Connectivism aims to bring together the networked nature of society into the learning constructs. In contrast to theories, such as behaviourism and cognitivism, which place learning as a separate inner construction of knowledge, connectivism emphasizes the importance of how and where to access information instead (Goldie, 2016). Moreover, the connectivism theory takes the stance that the information that exists would be too much for one person to be able to make sense of and is treated as internalized knowledge even though it is coming from external nodes (Goldie, 2016). By connecting a set of nodes of diverse opinions, knowledge, data, and meaning, continued learning is promoted. Thus, connectivism lends itself well to online learning where a learner can keep on learning no matter where they are based (Veletsianos, 2016). Without guidance the connectivism theory has the risk of adding information that is not relevant (Veletsianos, 2016).

Connectivism interestingly also adds that learning can happen between non-human instances, for example, in artificial intelligence uses (Reese, 2015). While connectivism fits exceptionally well with modern technological advancements to learning, it relinquishes control of the academic to a wealth of information that is dispersed and unstructured (Reese, 2015). Connectivism would be beneficial to a course where:

1.) Learning is collected in the diversity of opinions (Reese, 2015).

2.) Social collaboration is of high importance (Bair \& Stafford, 2016).

3.) Decision making itself is a process (Reese, 2015).

\section{Constructivism}

Constructivism as a theory suggests that learning is a learner focused constructive process and that students create and construct their own reality of learning using prior knowledge in constructing new knowledge (Jiang, 2019). The premise stated by constructivism emphasizes the active role that learners themselves play in constructing knowledge and inspires them to construct meaning from what they have seen, heard, did, and experienced. (Arghode et al., 2017). Forming the constructs is based on prior knowledge as well as constructing knowledge from others, and this leads the learning and knowledge formulation to be subjective in nature (Harasim, 2017). Thus, learners demonstrate understanding not just by repeating information but from demonstrating theoretical knowledge. (Juvova et al., 2015). In other words, the learner makes sense of their world by experiencing the learning and then constructing meaning (Johnston et al., 2018). Constructivism promotes a learner centred theory where experimentation and active participation is encouraged so that the learner can create more new knowledge and reflect on what was learned. By building on previous experience and knowledge, new learning can take place from a shared understanding between student and academic.

In the teaching environment, constructivism may be helpful where complex skills such as critical thinking and problem-solving must be grasped. The role of the teacher is set as a participant who encourages interactivity and helps the learner construct knowledge (Arghode et al., 2017; Hood Cattaneo, 2017; Usher et al., 2015). Critics of constructivism point out that constructivism is a reiterative process that re-examines problems continually (Tan, 2017). Furthermore, the argument is made that there is no emphasis on correct answers to problems, but a focus on the interpretation of the students' constructs (Tan, 2017). Proponents, however, argue that by engaging the learner by building on their experience, it promotes testing of knowledge in a meaningful manner. 
van Wyk, Johnston, Möller, \& Haas

Constructivist learning theory should be implemented with a suitable design method of motivating the student to encourage their willingness to participate and find meaning in the content. Cognitive and social presence are part of the constructivism view of shaping learning using interaction, collaboration, and dialogue (Scoppio \& Luyt, 2017). Constructivism is considered one of the leading learning theories in education (Amineh \& Asl, 2015).

Constructivism theory could be appropriate when developing courses where:

1.) The learner is in control of their learning (Usher et al., 2015).

2.) Group learning is encouraged (Amineh \& Asl, 2015).

3.) The process of knowledge construction is important (Tan, 2017).

4.) Tutoring and apprentice roles are required (Amineh \& Asl, 2015).

5.) Problem-based learning and brainstorming are implemented (Khalil \& Elkhider, 2016).

This led to the research question RQ2: Which learning theories would be best suited for developing a course for an emerging technology?

\section{COURSE DEVELOPMENT}

Students understand the benefit, impact and use of mobile web-enabled devices in their learning, and wish to use mobile web-enabled devices in classrooms (Abachi \& Muhammad, 2014; Benham et al., 2014). An impact on academics is that academics need to change and adapt their course development and teaching methods to incorporate mobile web-enabled devices into the classroom (Johnston, 2016).

Online teaching and learning have become commonplace and are widely accepted as an alternative to, and in addition to classroom-based courses (Kumi-Yeboah, 2018). Online learning has become an inherent part of many institutions' strategy and forms an essential facet in their plans (Kumi-Yeboah, 2018).

As the growth of online course delivery has expanded there has been an increased drive towards quality instructional design methods and the quality of the course material developed (Kumi-Yeboah, 2018). As a result, while technology evolves and more learners are considering online learning as an alternative study path, it is essential to further develop frameworks to develop online courses (Dumford \& Miller, 2018). Scoppio and Luyt (2017) stated that using connectivism and constructivism paradigms as theories to develop instructionally comprehensive learning could be beneficial to the course designer so as to develop online courses.

Since most academics have valuable experience in creating classroom-based courses, the fact that it requires a specific pedagogical approach to develop online courses is often not considered when they make the transition from classroom-based models of teaching to online teaching (Scoppio \& Luyt, 2017). Learning and perception can change depending on the technological situation (Scoppio \& Luyt, 2017). When classroom teachers are expected to teach online courses it has resulted in physical and conceptual gaps in communication and misunderstandings between teacher and student as Scoppio and Luyt (2017) discussed. The instructional model plays a significant role in the teaching design and learning process (Hess \& Greer, 2016).

\section{DESIGN MODELS}

The purpose of an instructional design model is to support learning designers and teachers to ensure that their teaching material and content is aligned in an optimum manner to aid the students learning development (Cheung, 2016). Instructional Design is the principles and procedures that apply to the consistent and reliable development of instructional material, content, information sources, lessons, and whole learning systems (Hess \& Greer, 2016). Instructional Design is a system based approach 
that follows guidelines, procedures and models as well as allows for evaluation of the educational design process (Hess \& Greer, 2016). Three design models, ADDIE, ARCS with the extension to ARCS-V and Bloom's taxonomy were reviewed.

\section{ADDIE Instructional Design Model}

The ADDIE instructional design model consists of five categories, namely, Analysis, Design, Development, Implementation, and Evaluation (Budoya et al., 2019). The ADDIE model is widely used in the instructional design and development field and often described as being instrumental to the improvement of teaching and learning (Cheung, 2016; Hess \& Greer, 2016). ADDIE continues to be one of the most popular and widely used models for instructional design (Ghani \& Daud, 2018). It is used as the blueprint to design applicable instruction and aids in providing methods for continuous evaluation and analysis of the content (Hess \& Greer, 2016). However, as described earlier by Hattie (2015), all learning design models have some form of improvement but that the specific model of design chosen, might not be the optimal way of delivering that particular learning content.

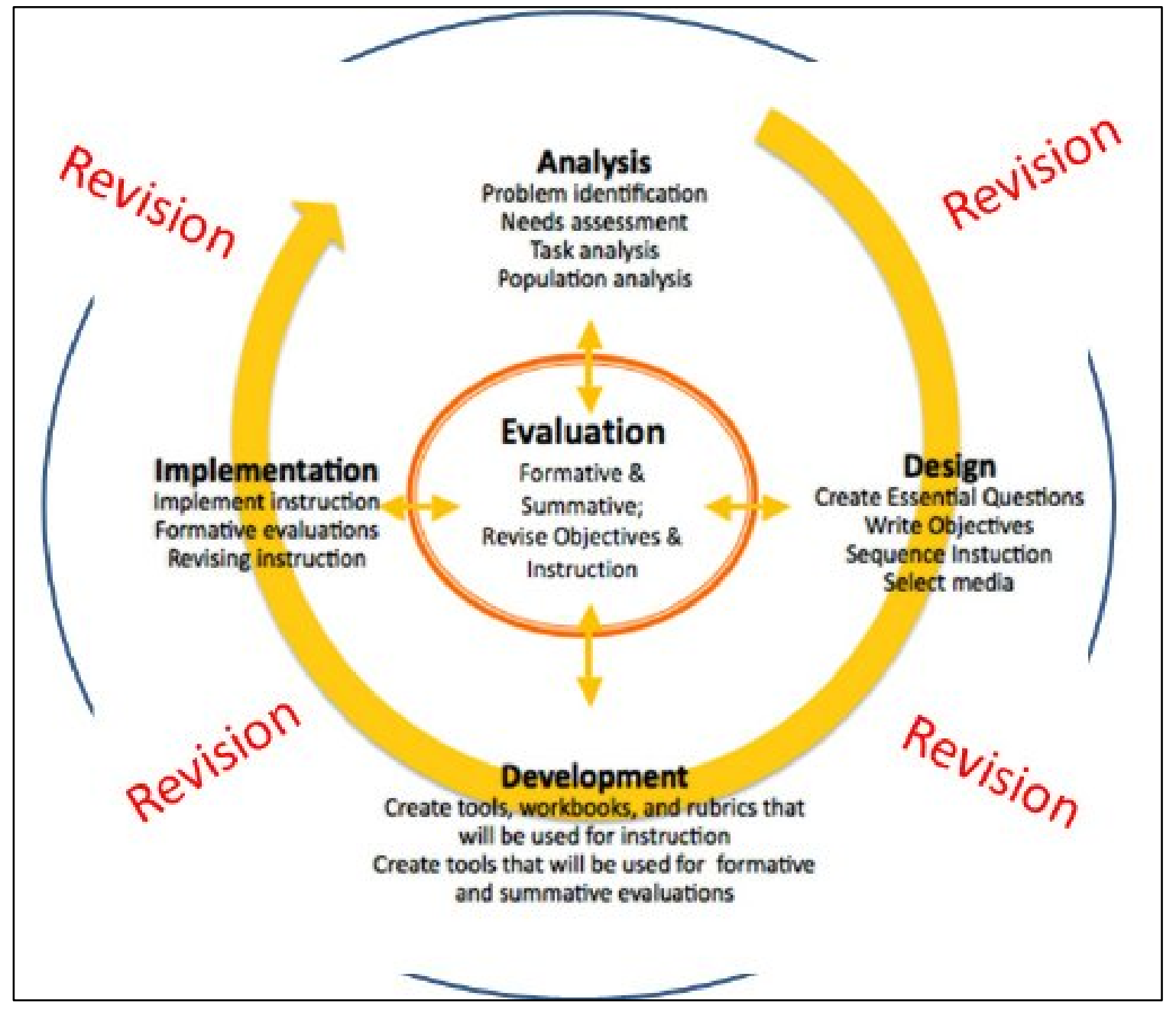

Figure 2. ADDIE Instructional design model (Shahril et al., 2015).

The different steps of the ADDIE instructional design model are used as follows, in the order ADDIE:

Analysis: In the analysis step the academic analyses the needs of the learners by looking at the educational objectives of the course and designing the outcomes to align with the 
van Wyk, Johnston, Möller, \& Haas

educational goals (Cheung, 2016). Some of the topics that need to be analysed could be how long a course should be or what evaluation criteria needs to take place (Trust \& Pektas, 2018).

Design: In the design step, academics need to develop the learning activities, assessment, and methods of delivery. In addition, they should develop the strategies on how to present the course material (Hess \& Greer, 2016; Trust \& Pektas, 2018).

Development. In the development step, the course creators develop the content assets and put all the materials together from the design step. Project review and fixes or changes are implemented and iterated upon, until the development of the course content is complete (Cheung, 2016). The reviews and iteration can be based on feedback from pilot studies or test participants (Hess \& Greer, 2016).

Implementation: Implementation is the next step in the ADDIE model. This step requires the designed course to be launched or delivered. In this step it is crucial to be aware of feedback from learners should there be any unforeseen issues in the delivery (Cheung, 2016).

Evaluation: In the final evaluation step the response from feedback and general usage of the course must be taken into consideration. These responses would then be used to re-analyse the course for a new design or to fix issues (Cheung, 2016).

Revision as on the arcs between the steps implies constant revision and assessment.

Even though the ADDIE model has been used in a vast number of instructional developments the model shows some disadvantages (Alnajdi, 2018; Jung et al., 2018; Nadiyah \& Faaizah, 2015). Although the ADDIE model focuses on systematic design procedures, the model has received criticism for being too inflexible and linear in nature, often being too drawn out and time-consuming for modern fast-paced learning (Jung et al., 2018). However, by applying some Agile methods to the ADDIE model it is suggested that these limitations can be overcome. Research done in improving ADDIE for multimedia and software development instruction found that adding a Feature Driven Development Process (FDDP) to the ADDIE model suitably addressed the limitations (Budoya et al., 2019). Furthermore, research has been conducted into extending ADDIE to include a course piloting step (X_ADDIE) (Constancio et al., 2018).

By using ADDIE in the instructional design process, it aids in keeping the complexities of learning design and instructional design at bay and increases the impact of the learning. A further benefit of using the ADDIE instructional design model is that different learning methods can be applied to establish knowledge acquisition by students of different learning styles (Alnajdi, 2018).

\section{ARCS/ARCS-V Motivational Design Model}

Motivation can be thought of as the learner's inclination to participate and engage in the learning, through cognitive, emotional, and practical application usually in an independent way, through difficulties and disappointments (Du Boulay \& Del Soldato, 2016). Motivation in learners is a key principle that drives learning, but in order to keep learners motivated it takes more than adding new technology to the online classroom. Using new technology helps, but when the novelty has worn off, academics need to have implemented instructional effective design and motivationally sound learning theories and models to keep the motivation level of the learner high (Libao et al., 2016). Keeping a learner motivated is a key factor in developing a successful instructional content (Khan et al., 2019). Whether online or face-to-face learning is taking place, positive learning cannot occur without the learner's efforts and willingness to learn and apply the concepts presented in the learning material. At the core, effective instructional practices should be accompanied by a sound motivated learner in order to promote learning (Arghode et al., 2017).

Each new technology application is accompanied by a predictable wave of publications describing its benefits and applications. However, the novelty effect associated with each of these innovations soon 
fades, leaving researchers with the continuing problems of providing learning experiences that are motivating to the learners and are instructionally effective (Keller, 2016). Certainly, adaptations of basic knowledge of motivation and learning have to be made by following the specific characteristics of a given technology or delivery system, but there are fundamental principles of motivation and learning that transcend these differences (Keller, 2016). Motivating and focusing on learning key skills is an integral part of building a functional and useful framework, and it begins with a discussion of issues related to technology and motivation.

The ARCS motivational model states that, "In order to motivate students, the instructor or instructional materials need to (1) catch and sustain students attention; (2) state why the students need to learn the content; (3) make students believe that they are able to succeed if they exert effort; and (4) help students feel a sense of reward and pride. The ARCS model utilizes a systematic process which can be specified into four steps: define, design, develop, and evaluate” (Li \& Keller, 2018, p.54).

The ARCS model presents a systematic design model to assist academics in creating course material and content with motivational elements for the learners (Keller, 2010, 2016; Loorbach et al., 2015). Intrinsic motivation creates a learner who is committed to learning the subject matter. The intrinsically motivated learner enjoys exploring and mastering the content and is more committed to doing so (Keller, 2016; Khan et al., 2019; Ucar \& Kumtepe, 2016). Figure 3 is a creation aid instructors can use to assess motivation (Keller, 2016). The ARCS model was based on previous research on human motivation. It is shown that intrinsic motivation increases learning engagement and improves academic performance in learners (Libao et al., 2016).

\begin{tabular}{|l|l|l|}
\hline Categories & Instructor's Self-Analysis & Instructor's Analysis of Learners \\
\hline Attention & $\begin{array}{l}\text { Am I excited about this learning } \\
\text { experience and how I can make it } \\
\text { interesting? }\end{array}$ & $\begin{array}{l}\text { Are the learners going to be interested? What } \\
\text { tactics will stimulate their curiosity and interest? }\end{array}$ \\
\hline Relevance & $\begin{array}{l}\text { Do I believe that this learning experience } \\
\text { will be valuable for my learners? }\end{array}$ & $\begin{array}{l}\text { Will learners believe it is valuable? What can I do } \\
\text { to help them believe it is important? }\end{array}$ \\
\hline Confidence & $\begin{array}{l}\text { Am I confident in my ability to lead this } \\
\text { learning experience effectively and } \\
\text { interestingly? }\end{array}$ & $\begin{array}{l}\text { Will the learners feel confident about their ability } \\
\text { to learn this? What do I need to do to help them } \\
\text { be confident? }\end{array}$ \\
\hline Satisfaction & $\begin{array}{l}\text { Do I expect to have positive feelings } \\
\text { about this learning experience? }\end{array}$ & $\begin{array}{l}\text { What can I do to help the learners feel good about } \\
\text { their experience and desire to continue learning? }\end{array}$ \\
\hline Volition & $\begin{array}{l}\text { Will I provide effective supervision and } \\
\text { support to the learners throughout this } \\
\text { learning event? }\end{array}$ & $\begin{array}{l}\text { What can I do to help the learners maintain their } \\
\text { goal orientation and task-focus throughout this } \\
\text { learning event? }\end{array}$ \\
\hline
\end{tabular}

Figure 3. Creation aid for motivational strategy design (Keller, 2016).

Keller first presented the ARCS model as a way to put the motivation of the student at the centre of the teaching and learning design (Chu, 2017). ARCS places motivation of the learner at the centre of the learning model in its entirety, meaning the motivational aspect continues through each step of the model. In time ARCS proved problematic in one aspect - the research showed that it did not account for learner persistence (Keller, 2016). Keller (2016) explains that some learners persisted in their learning and completed the studies even when motivation faded, while others would give up even though the end results were essential to them. To account for these differences in motivation a fifth category was added to the ARCS model, called Volition (see Table 1), creating the ARCS-V model (Keller, 2016). 
Table 1. Adapted ARCS to ARCS-V table.

\begin{tabular}{|l|l|l|l|l|}
\hline Attention & Relevance & Confidence & Satisfaction & Volition \\
\hline A1 Perceptual & $\begin{array}{l}\text { R1 Goal } \\
\text { orientation }\end{array}$ & $\begin{array}{l}\text { C1 Learning } \\
\text { requirements }\end{array}$ & $\begin{array}{l}\text { S1 Intrinsic } \\
\text { reinforcement }\end{array}$ & V1 Commitment to \\
learning
\end{tabular}

By using the constructivism theory as a guiding theory and applying the ARCS-V systematic design model to the design of the framework, a motivationally effective course outline can be developed that keeps attention, relevance, confidence, satisfaction and volition as guiding principles.

\section{Bloom's Taxonomy}

Bloom's taxonomy fundamentally organises thinking skills into six hierarchical organized categories that go from lower zones of thinking complexity through to higher zones of thinking complexity, as shown in Figure 4 (Fastiggi, 2019). The hierarchies are constructed from the verbs that the academic chooses when describing expectations for thinking skills and behavior in a learning outcome (Stanny, 2016). The lower complexity thinking zones attempt to establish a basis for the 'knowing' and 'understanding' aspects of cognitive skills, whilst the higher complexity cognitive thinking zones establish the basis of 'applying', 'analysing', 'evaluating', and 'creating' (Bertucio, 2017; Stanny, 2016).

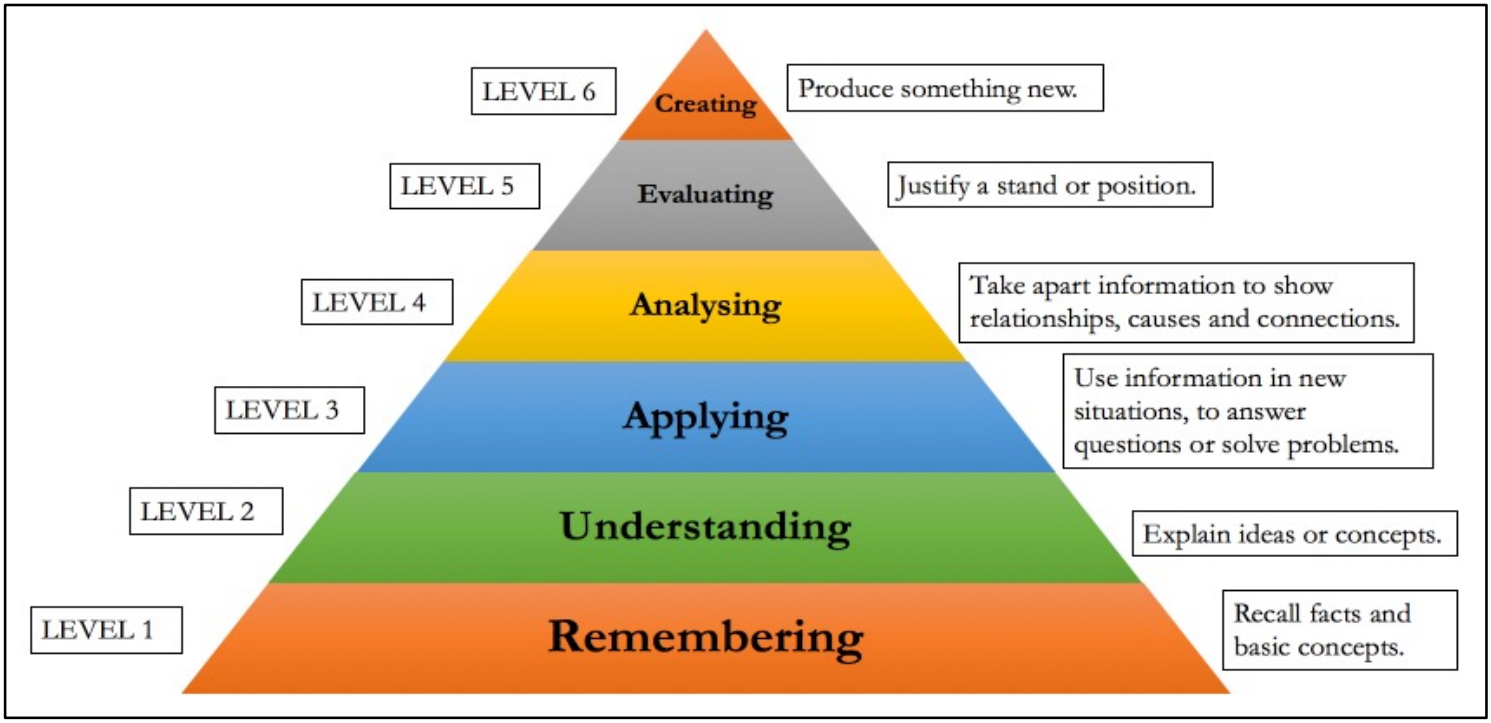

Figure 4. Bloom's Taxonomy (Fastiggi, 2019). 
The guiding principle built around Bloom's taxonomy assumes the keyword verbs in each category describe a progressive advancement of thinking skills. Thus, keyword verbs at the lower zones of Bloom's taxonomy define knowledge acquisition and fact memorization, in contrast the higher zones define more complex thinking skills such as applying the knowledge gained in lower zones to practical problems, analysing concepts and the creation of new knowledge or different interpretations of existing knowledge (Rahman \& Manaf, 2017; Stanny, 2016). Thus, by building learning activities based on these different levels of thinking skills, the progression from fundamental understanding to eventually creating new knowledge can be accomplished (Agarwal, 2019).

The literature led to the research question RQ3: Which design models could be used to construct a Course Development Framework for courses on emerging technologies?

\section{THE INTERNET OF THINGS (IOT) AND A COURSE REQUEST}

There is a sense that IoT will transform companies into digital business and change business models (Hung 2017; Tervonen et al., 2018). IoT applications and services will cover almost every aspect of the Supply Chain. For example, in transport management IoT will not only enable the monitoring of the precise location of transported goods but also control the conditions of the transport (e.g., shock, temperature) or storage conditions (e.g., flammable materials). Another example for IoT being the driver for a digitalized inventory management is the introduction of intelligent shelving and pallets (Witkowski, 2017). Future managers need to be prepared to manage this constant change not only by knowing the success factors but also the challenges, such as security, data integrity, decentralization, and confidentiality, by combining business excellence, process design and knowledge gathering. The very rapidly evolving IoT especially in combination with other emerging digital technologies like Big Data, Blockchain and Smart Contracts (Hong-Ning et al., 2019) will further stress the need to adapt also the educational approaches taken.

An Institute of Higher Learning requested a course be developed which aimed to provide students with an understanding of the complexities and issues involved in the Internet of Things (IoT). The name of the Institute has not been divulged for ethical reasons. IT professionals need to understand what Io $\mathrm{T}$ is, how it works, what the potential of IoT is, and how to use IoT to improve business. The course was to examine the broad concept of IoT in business, the sensors and devices (the 'things') that make up IoT, how the data is gathered and analysed, how the 'things' are connected, how cybersecurity is handled, and where the components sit, and how to manage IoT projects and the change they create. The course was to conclude with students creating and presenting an IoT concept design that solves a problem, and is ready to prototype and test.

The Io'T course was to use five approaches to ensure the student is active in constructing knowledge.

1. Supported learning - providing scaffolding and bite-sized chunks plus feedback. Providing students with readings.

2. Exploratory learning - students are encouraged to explore and discover new knowledge, to source videos.

3. Collaborative learning - students obtain multiple perspectives and critical thinking skills, and collaborate to produce presentations.

4. Problem based learning - students are encouraged to post problems, questions as well as answers on the topics.

5. Evidence Based Management (EBM) or practice, which uses four main sources of evidence: Scientific literature, Professional expertise, internal organisational data, and Stakeholders values and concerns. The EBM approach is Ask, Acquire, Appraise, Apply and Assess.

This led to the research question RQ4: How can the Course Development Framework be used to develop courses on emerging technologies? 
van Wyk, Johnston, Möller, \& Haas

\section{RESEARCH METHODOLOGY}

A research design methodology was used in the collection of the study data to develop and test a Course Development Framework. The research design choices were analysed using the methods Saunders et al. (2019) stipulated and depicted with the 'research onion' approach as a guide.

The research methodology explains the time horizon, research strategy, methodological choice, and approach. Furthermore, it explains the study's research philosophy. It continues to discuss the sample size and population, the research instrument, and the procedure of data collection as well as the validity. It then continues to cover some assumptions and finally discusses the study ethics. Figure 5 provides a summary of the research methodology.

\begin{tabular}{|cc|}
\hline Purpose & $\bullet$ Exploritory \\
\hline Philosophy & $\bullet$ Interpretivist \\
\hline Approach & $\bullet$ Inductive \\
\hline Time Horizon & $\bullet$ Cross-Sectional \\
\hline Strategy & $\bullet$ Qualitative \\
\hline Instrument & $\bullet$ Semi-Structured interviews \\
\hline Sample & $\bullet \mathbf{1 0}$ Experts/7 organizations/7 students \\
\hline
\end{tabular}

Figure 5. Summary of research methodology.

The research conducted a literature review to discover and explore learning theories, learning design methods, and models that would prove useful in developing a Course Development Framework.

To validate and test the framework, an IoT course was developed and delivered using the Framework.

The study was conducted only after consent was requested and received from the respondents. After approval and consent was received, data was collected by recording interviews using video chat services such as Skype, face-to face interviews, and email. The interviews were coded using qualitative data analysis methods to analyse the data inductively. The interviewee's behavior was also observed and noted where applicable.

The study used qualitative methods to gather information about past implementations and views about theories and frameworks as the respondents could discuss their experiences and provide insights.

The study chose an inductive approach as it is more flexible and can explore extra phenomena before making conclusions (Saunders et al., 2019). The respondents are skilled subject matter experts in education, Information Technology, and online education, thus each have possibly unique viewpoints based on their experience. Subject matter experts in Information Technology were approached from

South Africa, Netherlands, Norway, and Germany. The sampling size was 10 respondents from 7 different educational organisations that have expertise in IT course development. Using the expert sampling method, the study could gather data directly from specialist individuals. The names of the respondents were omitted for ethical reasons and were replaced by pseudonyms. The sample could be kept relatively small as the subject matter experts have relevant expertise in developing IT courses, learning theories, and online pedagogy.

The research instrument (available on request) takes the form of semi-structured interview questions. The questions were formulated from the literature review to verify elements from a learning development framework perspective and discover if the research aligns with current industry perspectives. 
Ethical permissions were obtained, and permission to conduct the interviews from each of the respondents.

The data gathered from the semi-structured interviews followed the six step approach of the thematic analyses defined by Clarke and Braun (2013). The thematic analysis approach is a method for identifying, classifying and examining the content in qualitative data (Clarke \& Braun, 2013). Thematic analysis is useful when analysing data from a wide range of questions, experiences, and understandings. Furthermore, it is useful when working with large or small datasets across varying data types such as secondary data, transcripts, interviews and other text (Clarke \& Braun, 2013). The six steps of the thematic analysis approach that the study used are shown in Figure 6.

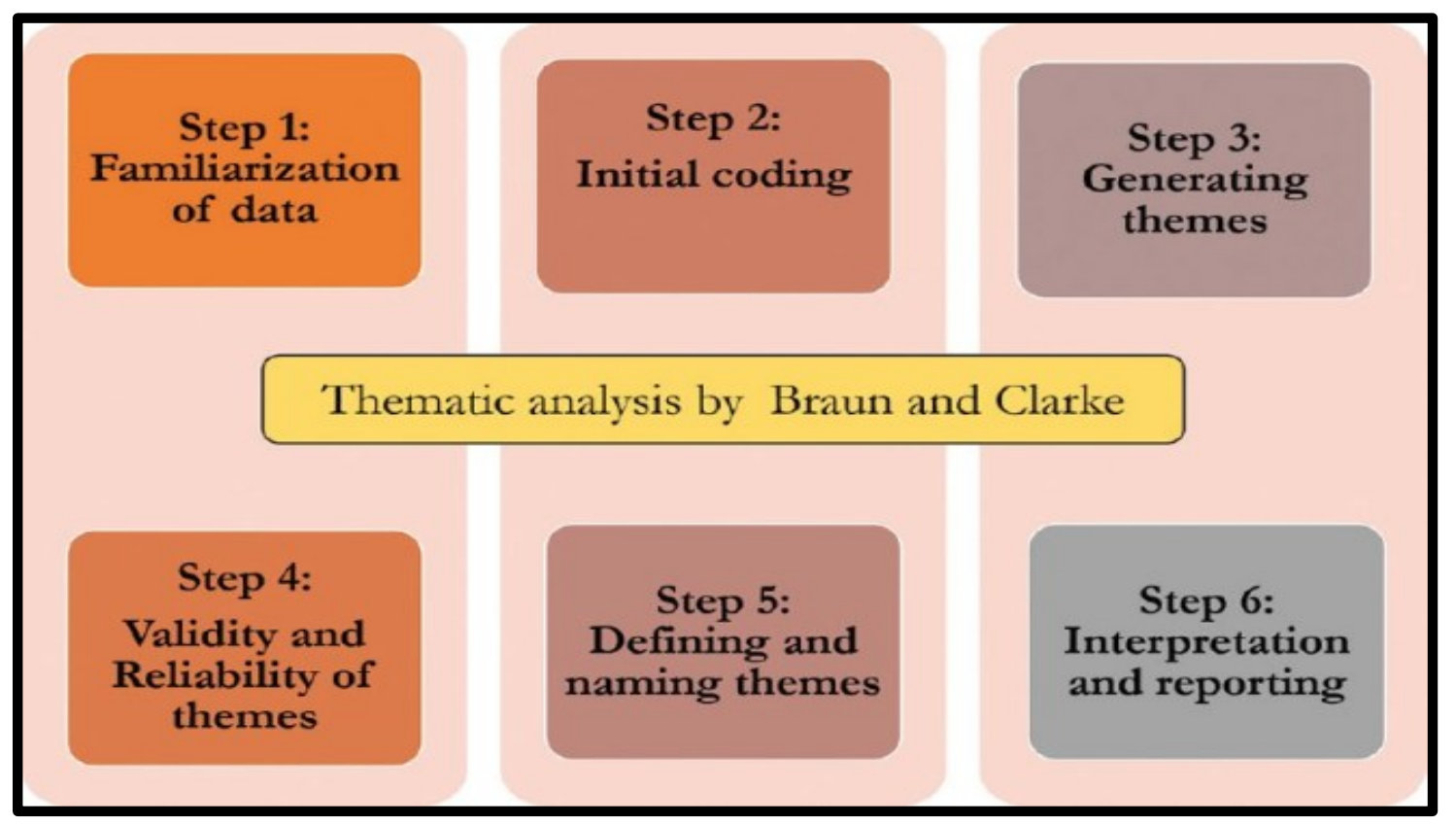

Figure 6. Thematic analysis (Eachempati, Kiran Kumar, \& Sumanth, 2016).

At the coding stage the respondents' real names were omitted and replaced with pseudonyms, those starting with an S (Sam, Seb, Sue, Sara, and Saul) were from a South African organisation, respondents pseudonyms starting with an N (Noa, Ned, and Nora) were from a Norwegian organization, respondents from a Dutch organization started with a D (Dave), and respondents from a German organization started with a G (Gavin). Seven students (or learners) who completed the course responded with feedback, each was given a pseudonyms starting with L (Liam, Lucy, Luna, Luke, Levi, Leo, and Leah), comments from four of the learners were used in this report.

\section{RESEARCH FINDINGS}

The research questions RQ1 to RQ4 are discussed in two separate sections. The first section on RQ1 and RQ2 reflects the answers to the structured interviews with the academics. The following two sections on RQ3 and RQ4 give answers separately how to construct and how to apply the Course Development Framework.

\section{LEARNING THEORIES IN DEVELOPING COURSES ON EMERGING TECHNOLOGIES}

To answer RQ1 and RQ2 on the use of learning theories within the Course Development Framework both the literature review and the respondents results were taken into account. 
The literature review identified several learning theories that could be used to develop courses, as Arghode et al. (2017) pointed out. One specific theory seemed to be especially suited for developing courses for emerging technologies, namely the constructivism theory (Scoppio \& Luyt, 2017). Educational experts were interviewed with regards to learning theories and course design. The respondents had a wide range of opinions of which learning theories are used, if at all, and what constitutes a good course design process. These varied opinions can be put down to varied experience within given areas of teaching.

Within course design and development, seven out of ten respondents claimed to use some form of learning theory. The research findings from the respondents indicate that three specific theories were considered, namely, Activity Based Learning, Bloom's Taxonomy, and Constructivism. One respondent (Ned) said he uses "no theories, but close adherence to Brain Compatible Learning principles, BCL", however BCL is not a learning theory, but an educational approached based on neuroscience and the biology of learning (van Niekerk \& Webb, 2016). The respondents' replies indicate that they might be using aspects of learning theories even though it is not explicit. Respondent Dave said that he does not use a theory, but he knows what works in his courses and what does not. "I don't use that. I just work with a structured course structure. I don't follow any particular method. It's a personal thing, but over the years you develop a feeling for what works in the particular area and in may of these theories is not applicable, especially in a field that is fairly new and where you are starting to discover what is important." Gavin said, "Although I am aware of several learning theories, I don't follow one, I rather use aspects of theories at various times. I can't believe that there is one theory which can explain how all individuals learn, I believe that each individual is unique and as such uses a blend of how to learn." Nora said, "the constructivism theory is a relevant view of reality,...... the theory aligns well as I draw on previous knowledge."

When the respondents were asked to place a value on a scale of 1 to 5 (1 being not closely, 5 being very close) on how closely they followed a learning theory, the results in Figure 7 indicate that of those using a learning theory three respondents followed a learning theory relatively closely by selecting a rating of 4 out of 5 .

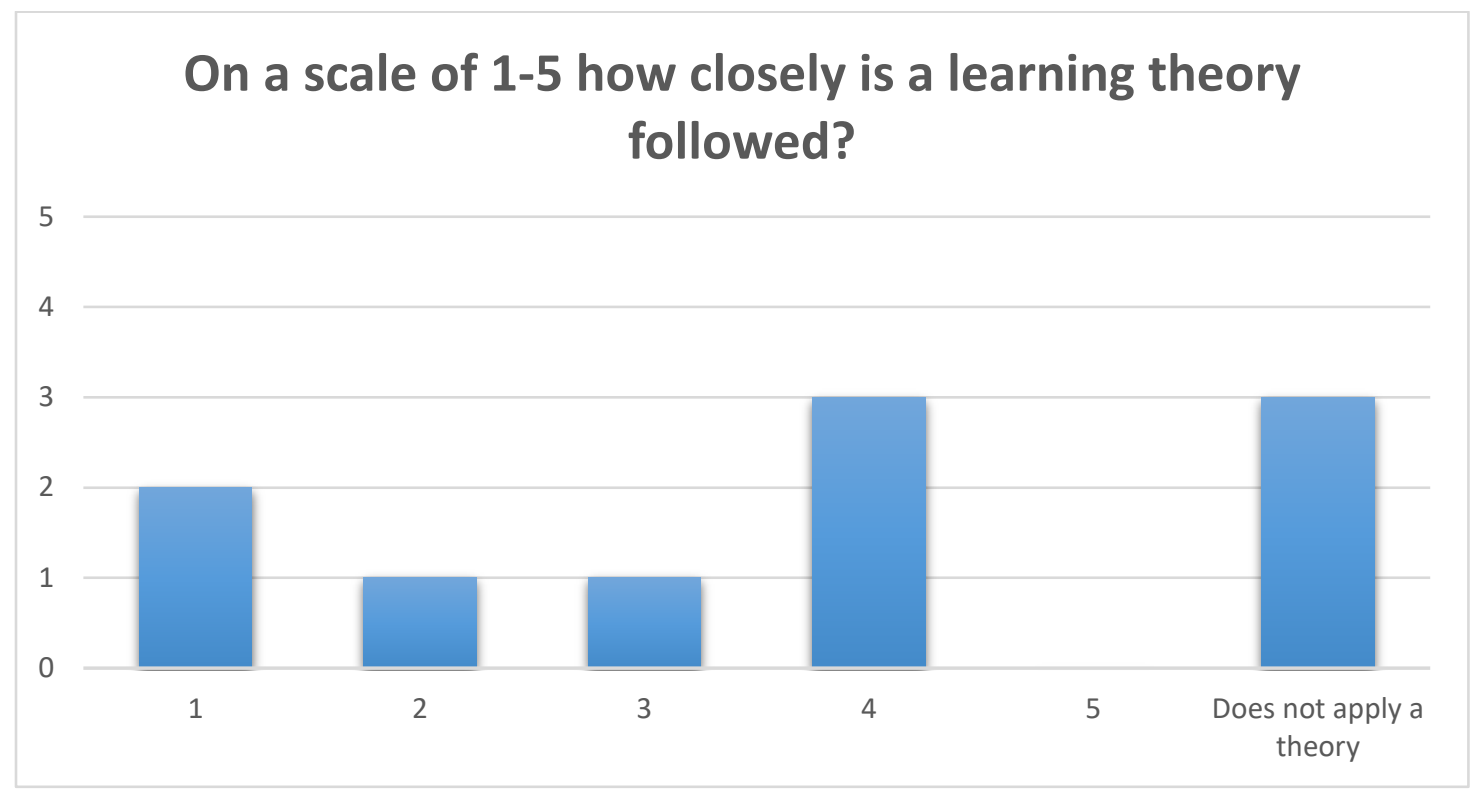

Figure 7: How closely are learning theories followed on a scale 1-5?

When inquiring why respondents follow or do not follow a learning theory, it was established that the lack of time and resources played a role when they did not use it. However, those that did use it mentioned that it plays a role in how the courses are developed. This is in line with the literature 
reviewed on learning theories. Those who follow the learning theory indicated that it's a good indication of how to develop a specific course. Noa said "This is a good indication of how one should develop a course to fit the different purpose and group that one targets. This has a major input into the assessment criteria and delivery model."

The finding is quite noteworthy especially in relation to RQ2 in that by outlining how a student learns and acquires knowledge, a learning theory can be used as a guiding principle so that courses can be developed in such a way that aligns to the specific area of study. A learning theory for courses in emerging technologies, such as an IoT, can make use of the constructivist learning theory for example and can be very useful from a course design approach to establish the importance of what types of learning takes place. The types of learning that are especially useful to an IoT course is contained within constructivism (Harasim, 2012; Tan, 2017; Usher et al., 2015).

Saul stated that he used the Constructivism learning theory, this is in line with the findings that were discovered through the literature review for use with courses where the focus is significantly learner centric (Arghode et al., 2017).

However, even though four of the respondents said that they do not use a learning theory, many said that they might use elements of a learning theory without knowing it. Thus, it is probably fair to assume that the respondents have acquired a 'feel' for what works for the students, and thus unknowingly use elements of theories even though they don't align it to the specific topics, as stated by Dave, "you develop a feeling for what works". This could also indicate that using a learning theory to guide the overall design of a course is perhaps not as important as that of experience in course design and teaching.

\section{RQ1 - Which learning theories could be useful as a basis to construct a framework for developing courses on emerging technologies?}

Many learning theories could be used to develop courses such as behaviourism, cognitivism, connectivism and constructivism. However, choosing a fitting learning theory would enable the academic to better decide which types of learning activities and assessments to create.

\section{RQ2 - Which learning theories would be best suited for developing a course for an emerging technology?}

Regardless of the fact that only three respondents used constructivism this research has recommended that constructivist learning theory should be used for an emerging technology course such as an Io'T course. Constructivism theory is a suitable theory for emerging technologies as it encourages active learning and builds on previous knowledge.

\section{DESIGN MODELS FOR THE COURSE DEVELOPMENT FRAMEWORK}

The original research question was: RQ3 - Which design models could be used to construct a Course Development Framework for courses on emerging technologies?

Both the literature review and the respondents results from the pre-framework questions were considered in answering this research question. When the literature review was conducted it became apparent that the ADDIE Instructional Design model was touted as very significant in the learning field (Budoya et al., 2019). When the respondents were asked if they have heard of the ADDIE model, surprisingly, four of the respondents had not heard of the model and only four had used the model as shown in Figure 8, one respondent declined to answer this question. 


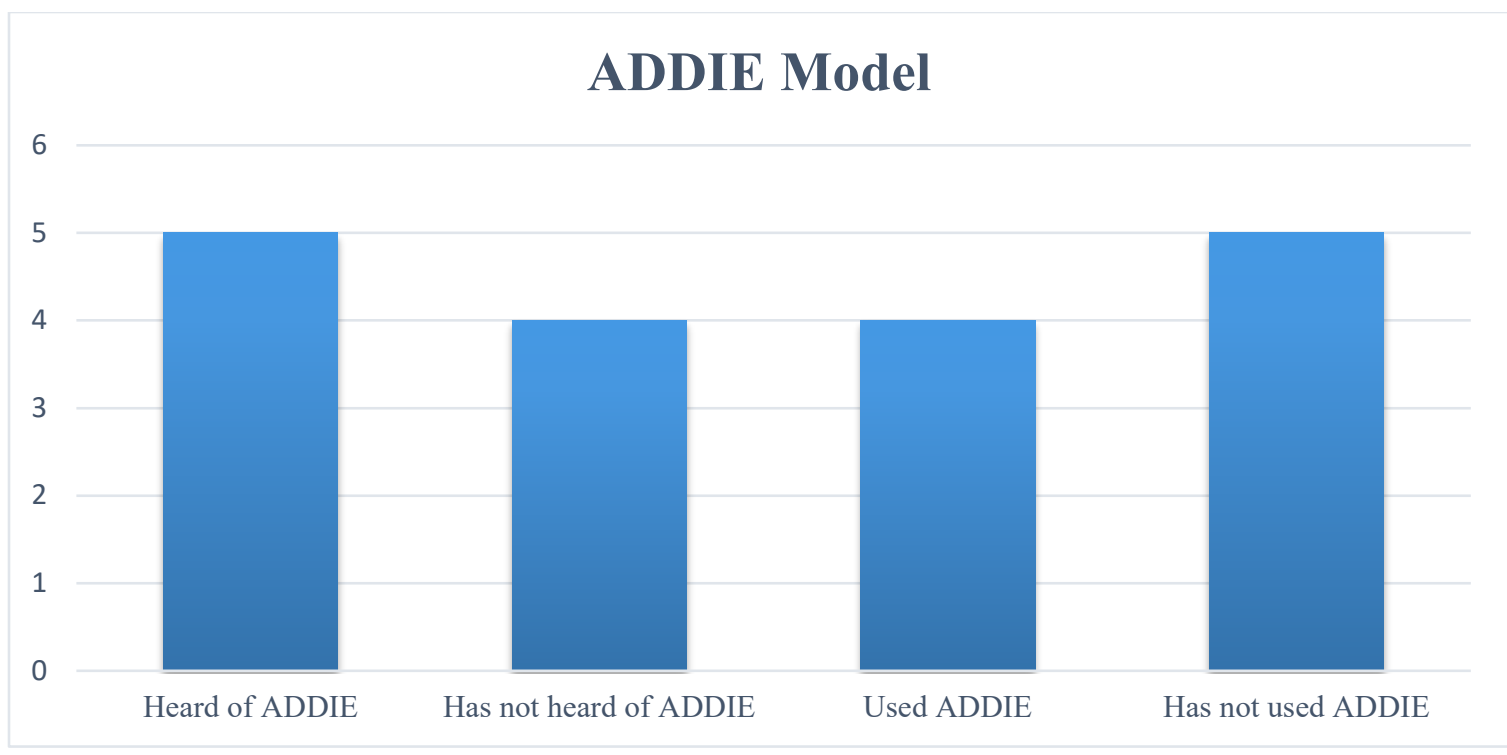

Figure 8: ADDIE Knowledge and use.

Sam said “One doesn't use one approach alone. I read a lot about teaching and learning....it's difficult to keep the motivation...... probably use parts of it but I don't use it in a formal manner. I may use aspects of ADDIE but I wouldn't necessarily follow it to the T." Gavin said, "Of course I know ADDIE, and of course I use ADDIE, it a very typical process, nothing special." Seb said he had never heard of ADDIE or ARCS models.

Through the literature review, it was discovered that ADDIE is an excellent instructional design model and still in extensive use with a valid design model (Cheung, 2016; Hess \& Greer., 2016). For the reasons listed in the literature review, the ADDIE model was subsequently chosen as an Instructional Design Model for the Course Development Framework.

Although Bloom's taxonomy was not looked at when the literature review was first conducted, many of the respondents used Bloom's taxonomy, either as a learning theory or as a method to design learner outcomes or in a design process. Respondents that mentioned Bloom's taxonomy in the PreFramework interview included Noa, Sam, Saul, and Gavin. Sam said, "I use the Bloom Taxonomy most of the time and then that's also what I share with the class." Gavin said, "I use Bloom's taxonomy to develop learning outcomes at the beginning of designing a course, and when developing examination questions."

The researchers then conducted a literature review regarding Bloom's taxonomy and found that it could indeed be a valid and useful method to incorporate into the Course Development Framework to establish the levels of learning of the learning outcomes as a whole (Agarwal, 2019; Bertucio, 2017; Stanny, 2016).

The researchers discovered through the literature review that keeping the learner motivated is an essential aspect of developing successful instructional content (Keller, 2016; Khan et al., 2019). Similarly, motivation and keeping motivation high in courses resonated with the respondents as an important aspect and an issue. However, none of the respondents followed specific formal models or theories to motivate students in their learning or course creation.

The ARCS-V motivational model was identified in the literature review as a potentially positive model to introduce as an overarching motivational design in the Course Development Framework. When inquiring from the respondents if they had heard of the ARCS-V model or had used the ARCS-V model only two respondents had heard of the model, and no respondents had used the model at all. This could indicate that the ARCS-V model is not as popular as thought, or that the 
respondents did not know about the model. However, given the experience level of the respondents and the high level of interest in the motivational aspect of learners, the researchers expected that the respondents would use some sort of motivational design or model in their course development. Further data from the interviews concluded that no respondents used any models or frameworks as a guide to motivate students. This finding is quite surprising when considering how high the importance of keeping learners motivated ranked with the respondents.

The following comments with regards to learner motivation were made by the respondents. Dave said, “....once they've lost interest it is very difficult to pick it up again," and "If you don't force them to do assignments to keep busy, they will tend to drop out." Sue said, "It depends on why the student is there doing the course, is it because they were told that they have to be there or because they are interested. Part of the motivation is why they are there in the first place." Gavin said, "I try to motivate students by providing facts, examples and stories. I try provide students with ideas to help them imagine their tomorrows". Noa said, "I like to motivate students by showing them a functional and practical use of every concept they learn. I try to make it relevant to them as individuals." Sara mentioned that they do not use a model, but that "Group work" or "Group activities" are used to help motivate learners.

The data from the answers toward the motivational model questions indicates that the respondents do not use motivational design models in the course design. However, the qualitative data analysis produced data that shows that it does not necessarily mean that there are no motivational elements included in the design. When theming the responses from the respondents and mapping it to the ARCS-V motivational model discussed by Keller (2016), the academics were describing elements of ARCS-V unknowingly, the responses showed that many of the respondents are indirectly considering elements of ARCS-V as necessary. The relevance of the course and keeping the attention of learners ranked highly when academics are designing courses, which was supported by the literature review and the discussion of the ARCS-V model (Keller, 2010, 2016). The finding is significant as this indicates that including the ARCS-V model into a course design framework would prove to be of use to academics and provide a positive impact. This led to the incorporation of the ARCS-V as a motivational model in the Course Development Framework.

\section{A Course Development Framework for emerging Technologies}

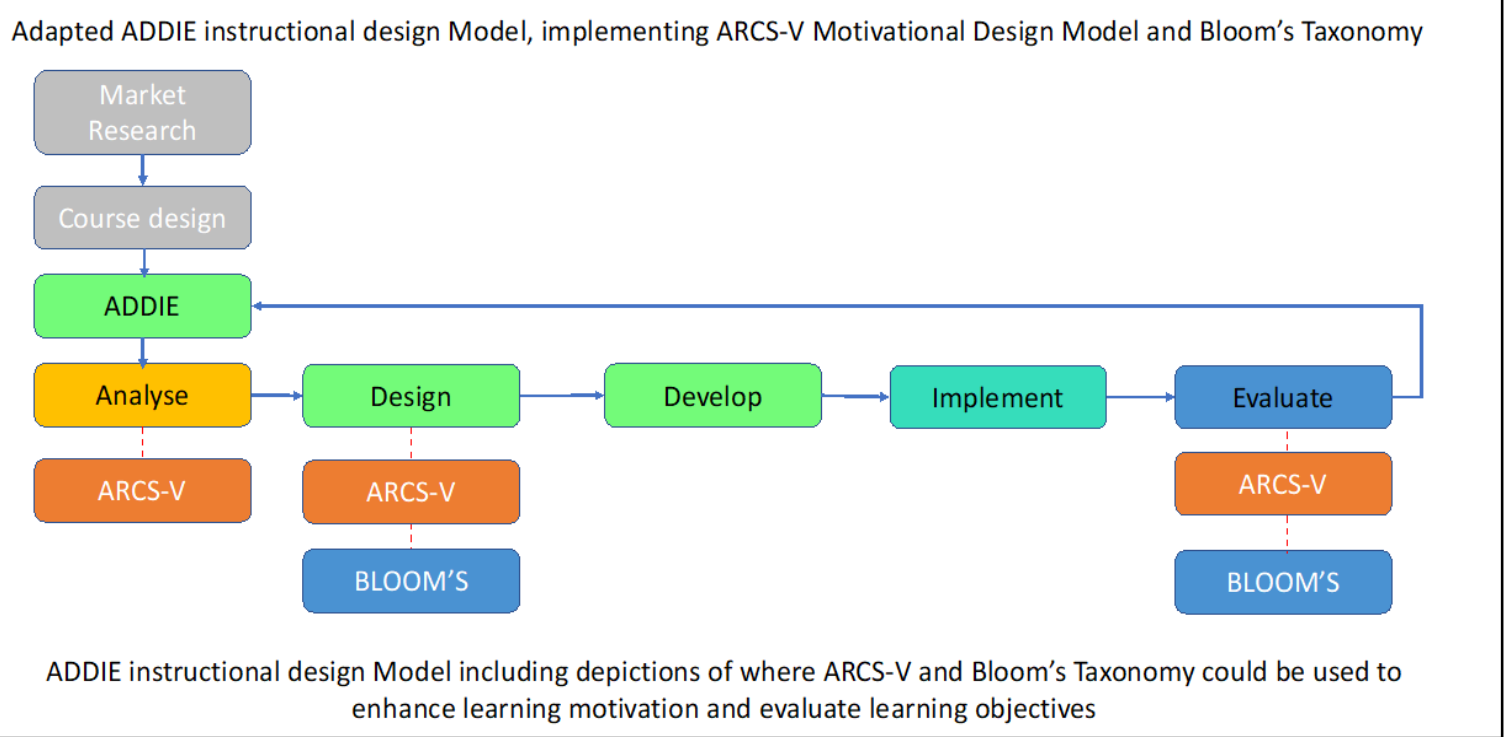

Figure 9: Course Development Framework for Emerging Technologies (van Wyk, 2019). 
With the findings from the literature review and the feedback from the respondents it was found that there are a few established models and methods available for course design that can be incorporated into an Course Development Framework.

A relatively well used instructional design model, ADDIE, can be used to design a course, as it provides for the analysis, designing, developing, and evaluation of a course as discussed earlier. However, it lacks the motivational design elements that ARCS-V can provide. Motivational design elements proved to be an issue for the respondents as can be seen from the responses. The ARCS-V motivational model could be used in an Course Development Framework to provide motivational design elements. Furthermore, Bloom's taxonomy could be incorporated in the Course Development Framework as a method to evaluate the learning levels of the learning objectives as was discussed in the literature review. By using the answers a Course Development Framework was created as shown in Figure 9.

\section{Analysis Phase}

Figure 10 details the Analysis phase of the Course Development Framework. In this phase, a course designer should do a variety of activities, including: considering the relevance of the course (which emerging technologies or concepts will be delivered?), conduct market research (what are others doing, what is relevant to the industry or field?), consider the target audience and pre-requisites (agegroup, education level, skills, admission requirements, career possibilities, etc), identify and gather relevant academic and research papers. Additionally, learner outcomes (purpose of course) and Learning Objectives of the course have to be defined, and module and assessment criteria defined.

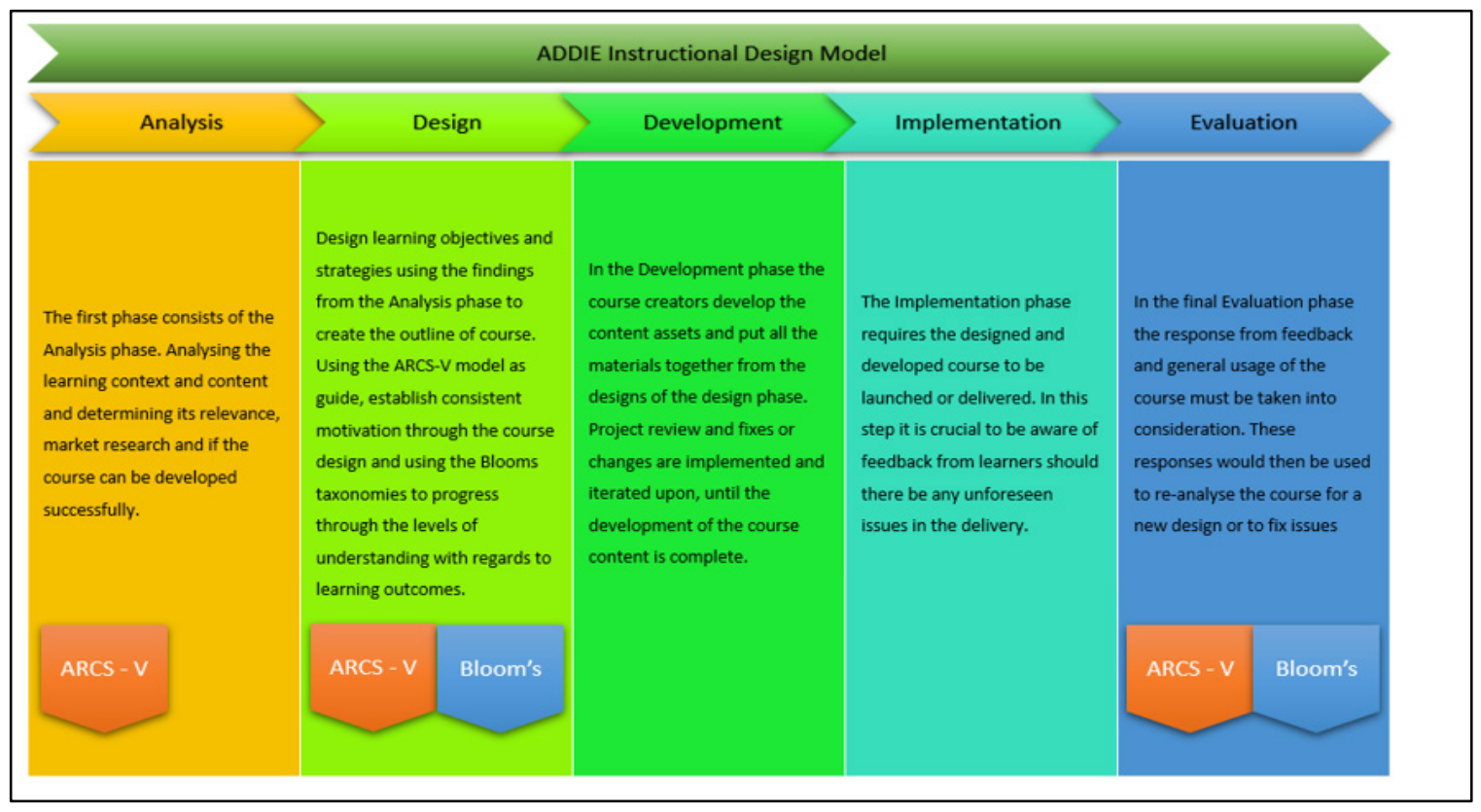

Figure 10: The Analysis Phase of the Course development Framework (van Wyk, 2019).

\section{Design Phase}

In the Design phase, academics need to develop the learning activities, assessment, and methods of delivery. In addition, they should develop the strategies on how to present the course material.

When designing the course, a learning theory and philosophy can be considered. Constructivism theory fits well for technologies, such as IoT, VR, AI, Robotics, Game Development, or 3D Design, since it encourages active learning. Choosing a fitting learning theory will enable the educator to decide which types of learning activities and assessments to create. The Design phase should be 
developed by building in learner motivation by using the ARCS-V elements (Attention, Relevance, Confidence, Volition) as guide to see if each element of the course contains one of these aspects and all aspects in each module or lesson if possible. Bloom's Taxonomy should be used to design the learning objectives using ARCS-V to guide the motivational aspects of the course design.

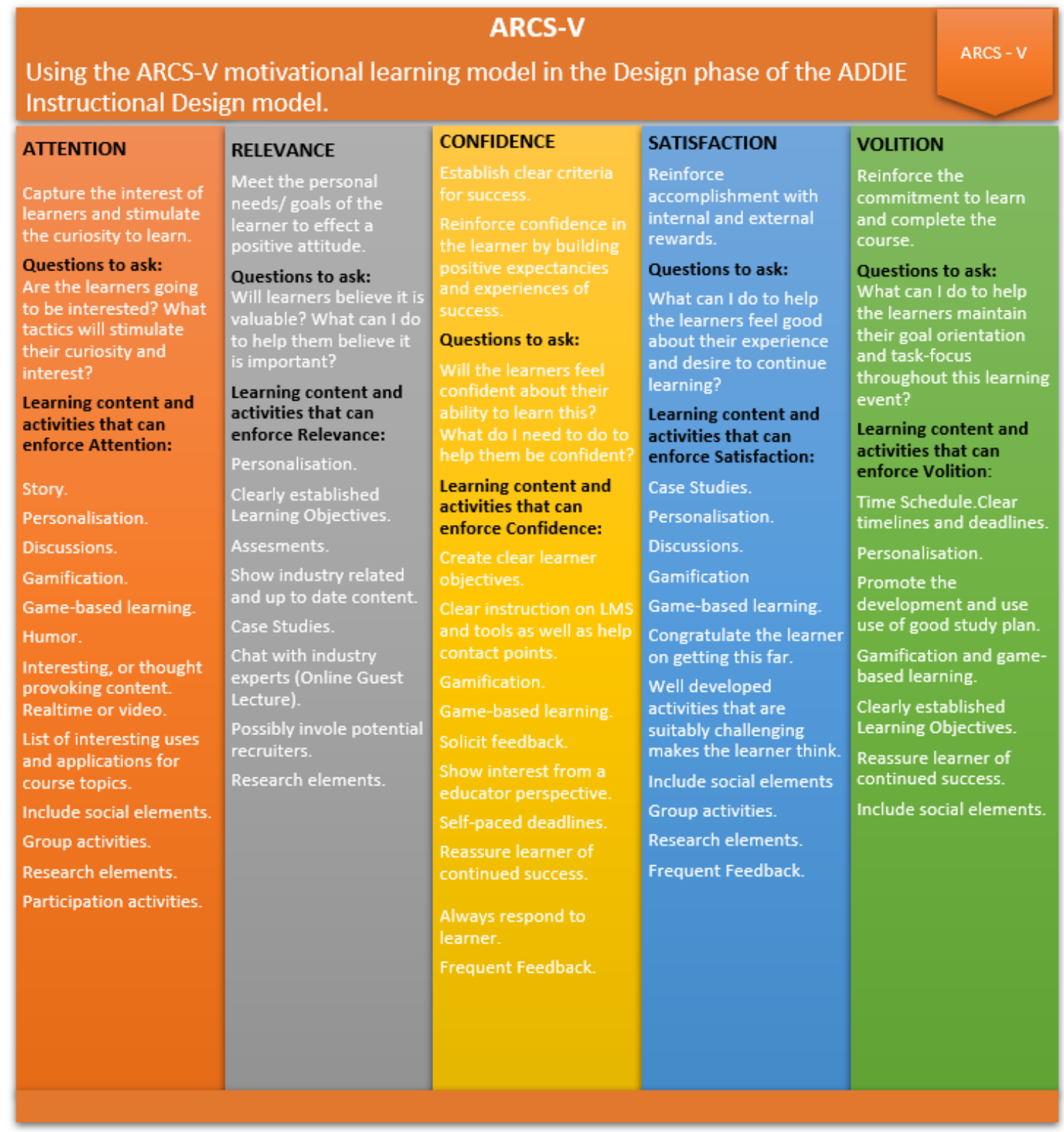

Figure 11: Using ARCS-V in the Design stage of ADDIE (van Wyk, 2019).

Figure 11 shows a course designer how to use ARCS-V in the Design stage of ADDIE. In the Design phase of the Course Development Framework, a course designer needs to decide on IT requirements, platforms, systems, bandwidth, etc. for course delivery, facilitation, and student participation, taking user experience and accessibility options into consideration. Learning activities should be designed by using motivational aspects in learning (use ARCS- $V$ to guide the motivational design). Learning objectives and assessment methods should be designed using Bloom's Taxonomy (Planning verbs), clear evaluation criteria need to be created and made available. Designers should consider designing interactive content (Attention, Satisfaction, Relevance), using short videos to grab learner's 
attention, include examples that might be useful and relevant to the students. Frequent feedback should be provided (Confidence, Satisfaction). Appropriate assessments (Relevance, Confidence, Satisfaction) need to be defined, and Game-based learning considered (Attention, Confidence, Satisfaction, Volition). Ensure the learning activities use multiple methods of learning if possible, and reflect on the learning objectives from the learner's perspective and align the learning activities to them.

\section{Development phase}

Figure 12 shows the Development phase of the Course Development Framework.

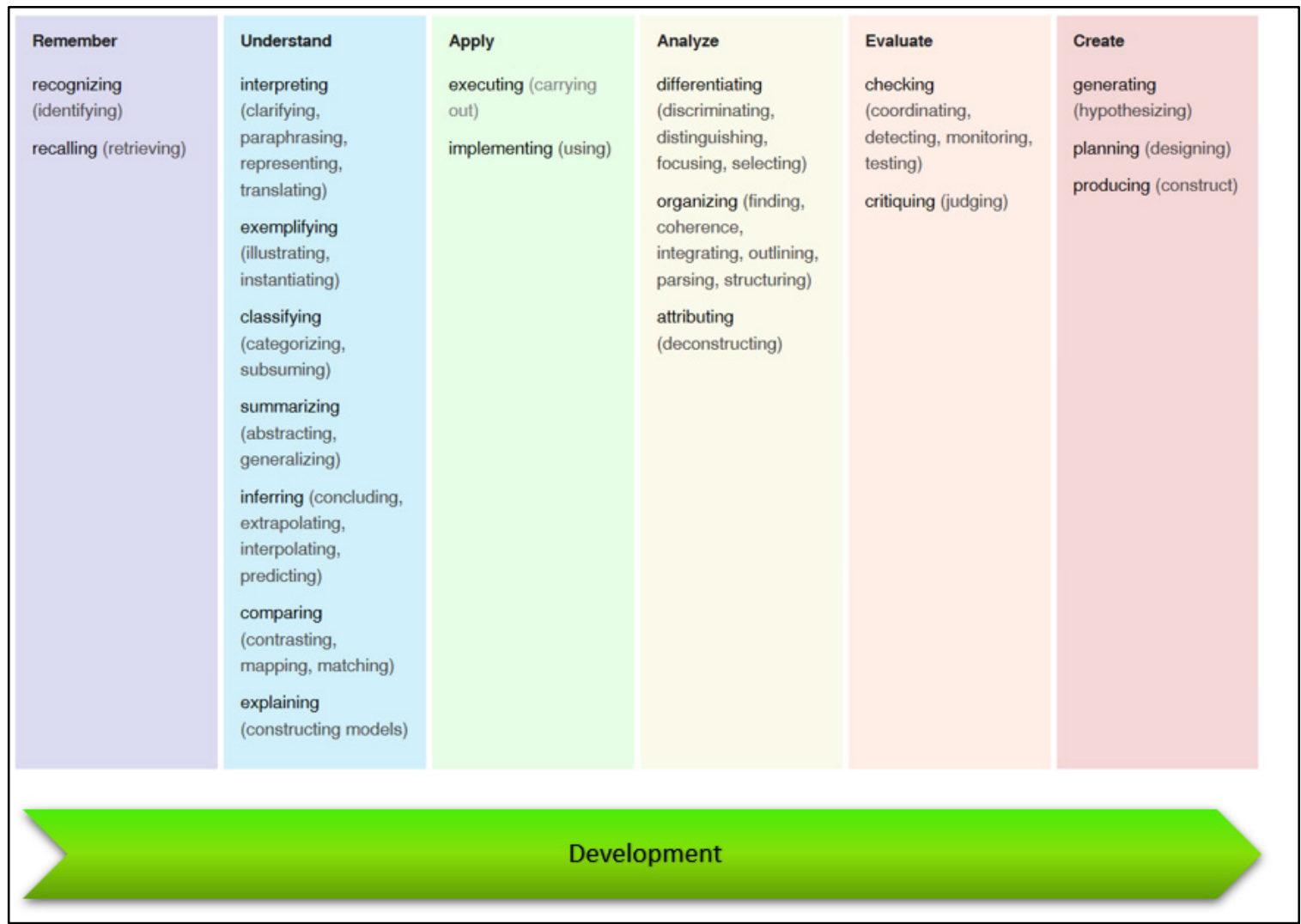

Figure 12: The Development Phase of the Course Development Framework (van Wyk, 2019).

In the Development phase of the Course Development Framework the academic analyses the needs of the learners by looking at the educational objectives of the course and designing the outcomes to align to the educational goals. The academic needs to develop activities and content that will help the learner improve performance. The content and activities need to be developed, and one must consider how it will integrate with the Learner Management System (LMS). When developing content consider the tone, readability and context of the writing style, and try develop interactive content. An academic should set up and develop social interaction areas.

\section{Implementation phase}

In the Implementation phase of the Course Development Framework, the learning material and activities are put into practice and the learners are given access to the course. This phase is an active involvement phase and the educator should be well prepared to deal with learner questions and issues. Use ARCS-V to check if initial analysis is correct. Use Bloom's taxonomy to check if learning outcomes and objectives are still in line with data from the Design phase. 


\section{Evaluation phase}

In the Evaluation phase of the Course Development Framework, a course designer could assess if the course was successful and effective. It also identifies if there are any issues present and if any aspects of the course can be improved upon. The designer will then go through the Analysis, Design, Development and Implementation steps iteratively to improve the course. Look at ways to continually enhance the course. Collect data on learner engagement and activity (Did learners' access and start the course, where did they spending the most time and the least time)? Collect feedback from learners (Survey/Polls/Reflections) to determine satisfaction and performance of the course.

\section{THE DEVELOPMENT OF THE IOT COURSE USING THE FRAMEWORK}

Research question RQ4 was, "How can the Course Development Framework be used to develop courses on emerging technologies?"

An IoT course outline was chosen to build a test case for the Course Development Framework as such a s course was requested by an institution. The Course Development Framework detailed in Figure 9 was used to build an IoT course. Figure 13 shows the Course Description for the IoT Course, including the topics or modules to be covered, and Figure 14 shows the overall assignments and grading values.

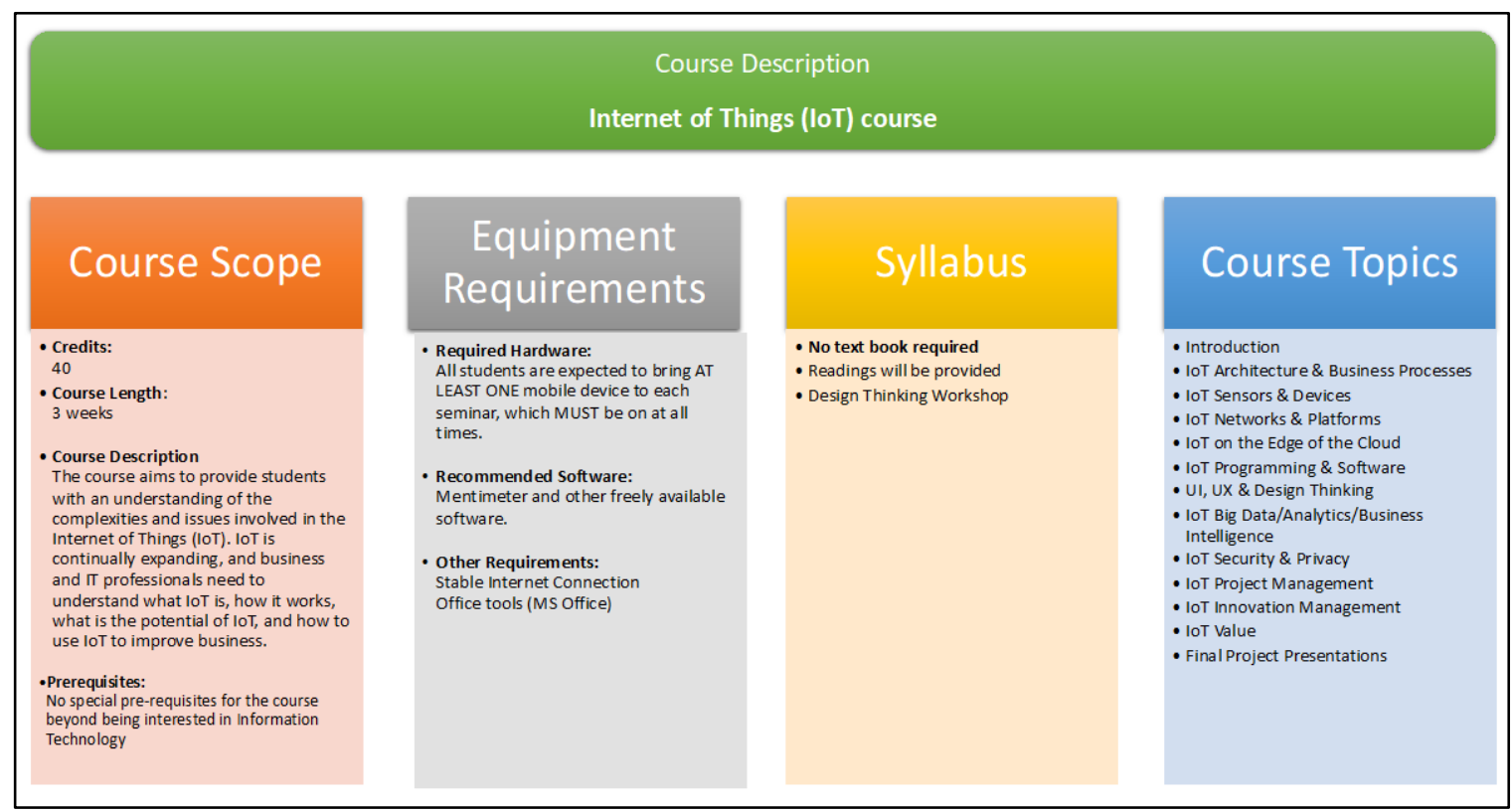

Figure 13. Course Description for the IoT Course.

\begin{tabular}{|l|l|}
\hline Assignments & Grading Total Values \\
\hline Participation/Answers/Questions in seminar & $20 \%$ \\
\hline Videos in Seminar & $20 \%$ \\
\hline Reflection & $10 \%$ \\
\hline Final Project Presentation & $50 \%$ \\
\hline Total: & $100 \%$ \\
\hline
\end{tabular}


Figure 14. The assignments and grading values.

Figures 15 and 16 show two of the topics (modules 3 and 8) for the IoT course- obviously one would need need to build one for each module of a course. The blue blocks shows the Bloom's Taxonomy levels for each part of the Learning Outcomes, while the orange blocks show the ARCS-V criteria for each of the chosen activities, assessments and course content.

The mixed project-based approach that an IoT course required the need for a theory that can be used to draw knowledge from various different areas (Liagkou et al., 2019). Thus, the framework needed to make use of a learning theory that promotes an open approach to design interpretation as well as build upon previous knowledge gained as the student progresses through the course. Constructivism fulfils these requirements as discussed (Harasim, 2017; Jiang, 2019).

ARCS-V was used in combination with the constructivist theory and Bloom's taxonomy to develop a framework for an IoT course outline. The ARC-V motivational model was used to establish motivation as a fundamental guiding principle in the course outline. ADDIE has been previously used with the constructivist theory as shown in the paper by Trust and Pektas (2018); ARCS-V adds the required motivational elements as it allows for a motivationally aligned learning methodology while being flexible and focuses on learners. Bloom's taxonomy establishes the learning levels of the learning objectives.

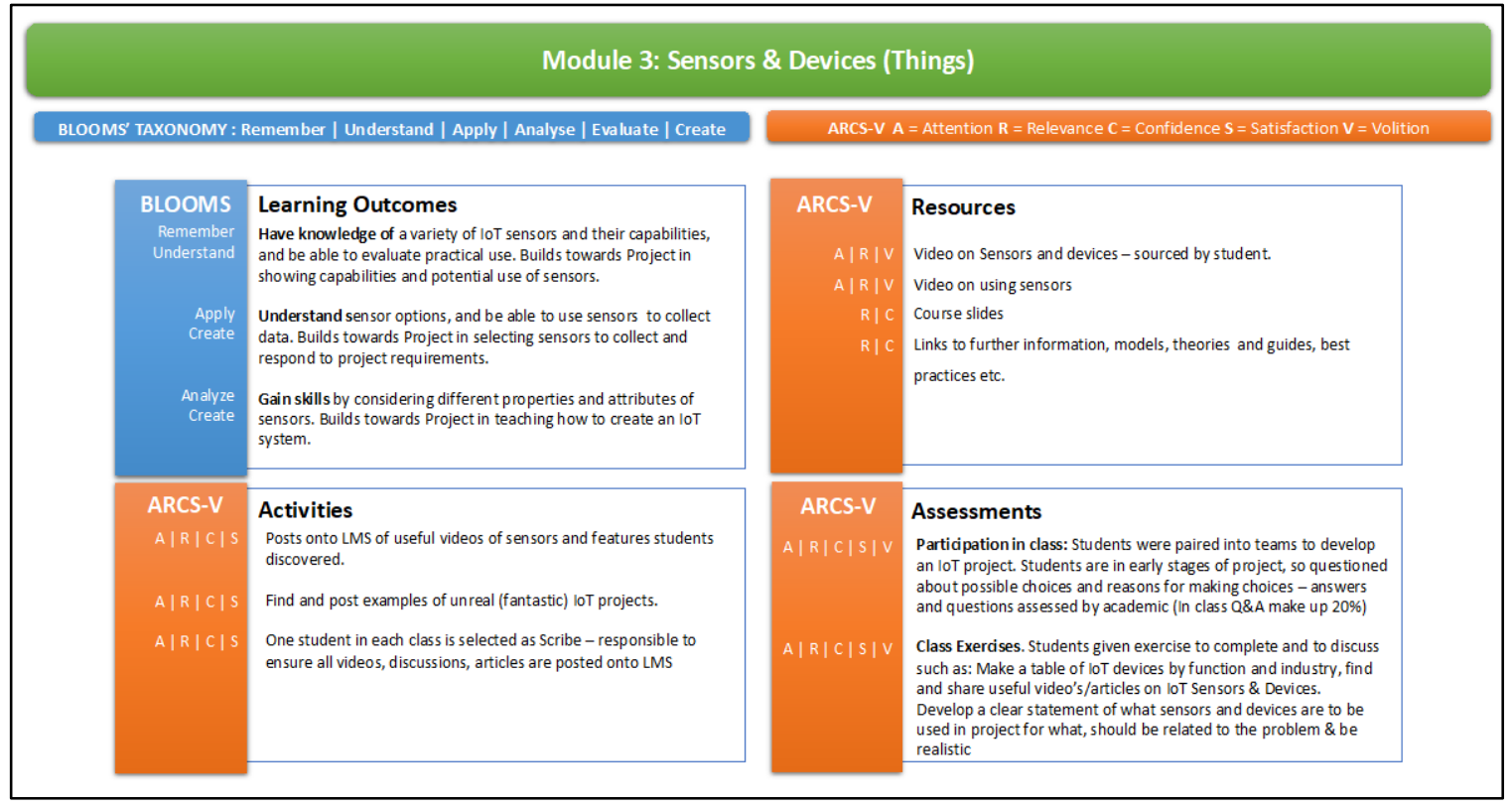

Figure 15. Module 3 of the IoT course. 


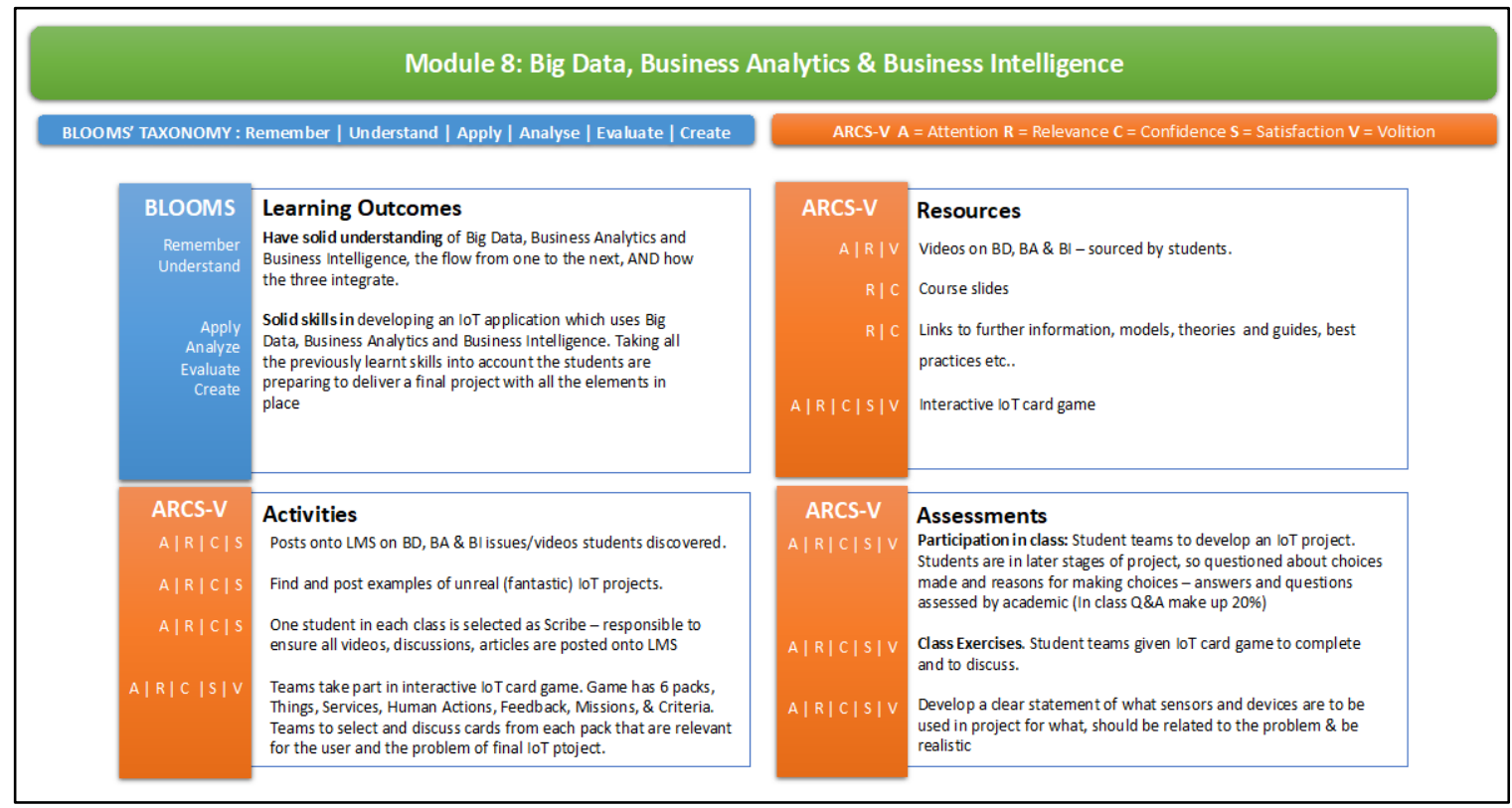

Figure 16. Module 8 of the IoT course.

Similarly to the ARCS-V model, the constructivist theory focuses specifically on learners. When considering the learner, the constructivism theory takes into account learners' previous experiences and knowledge around the subject (Juvova et al., 2015). The ARCS-V model emphasizes the learners' motivation and strives to engage by first grabbing attention, showing the relevance and instilling the confidence that is needed (Keller, 2010; Li \& Keller, 2018). Building a course, the instructor needs to establish motivation as well as provide a non-rigid approach to the students' delivery of activities. The course activities should provide a choice of themes or ask the students to choose their own ideas as a development project and in doing so, provide satisfaction by seeing their ideas brought to reality through the coursework (Keller, 2016; Trust \& Pektas, 2018).

The course design for the IoT course began by describing to students what the course will cover, what the students can expect, and what the students are expected to deliver. Using examples that bring the previous experience into consideration, the academic developed activities that show how the learning made use of existing skills (Arghode et al., 2017). The material clearly pointed out the learning outcomes that students will accomplish by participating in the learning material and activities (Czerkawski \& Lyman, 2016).

\section{RESPONSES FROM STUDENTS}

As part of the course students were expected to submit a reflection piece (maximum 250 words) a maximum of a week after the final lecture.

Liam stated that the course taught him to "Never stop asking questions. ...I have unfortunately often neglected to do this." Lucy agreed, "I learned to ask without any hesitation."

Lucy commented about IoT as follows, "Maybe I knew how the all thing worked but I realised more about it in the class," and Luke said, "I learnt many new things and I found the course really beneficial for my career." Luna said, "This course really helped me to gain perspective about IoT in overall. ... I learned much about IoT and IoT applications.”

Luke stated, "The methodology COLLECT, CONNECT, ANALYSE, ACT gave me the key strategy to work on any project and in any environment." Lucy added, "I realised more about it in the class that everything you do in projects, class, work or life it's almost to collect information, to connect them, to analyse them and then act on them." 
Liam said, "The class exercise which we did, it showed me, that by exchanging your ideas with others will lead you to some greater and better ideas." Lucy commented, "By giving us a small project to encourage us to think about new ideas the way IoT can work further."

Luna said, "This course really helped me to gain perspective about IoT in overall," and "I gained perspective about IoT in an interactive way." Luke added, "This course helped me out to understand the broader aspects of IT and internet of things with real picture (discussion) and real examples with analytical thinking and scope in future.

Luna said, "The course changed my opinions about DATA as I always thought the data analysis are kind of useless thing in today's world but I realised that data management gives you real information to act and helps the person to identify problems, making decisions and bringing in new criteria."

There were supringly few negative comments, although students were asked to list both positive and negative comments. Lucy said, "Class afterwards were not that enthusiastic as the first ones," Liam said there were "to few classes, more of such classes are more beneficial."

\section{CONCLUSION}

On the outset of this research study, the aim was to discover if a useful Course Development Framework could be developed that would support academics in the development of courses for emerging technologies.

Through the literature review it was discovered that learning theories could play a significant guiding role in the development of courses. However, the study found that academics don't explicitly use learning theories when developing courses and that this was attributed to academics feeling that having developed courses, they had a 'feel' for what works and what does not. This study found that constructivism is well suited for emerging technology courses because of the nature of building on previous knowledge and putting the learner at the centre of the learning experience.

The ADDIE instructional design model was found to be relevant and well suited for course development. It was found that academics do not use motivational models in their course design, but that they once again use the experience to guide them as to which aspects would guide learners and keep them motivated. This research found that the ARCS-V motivational design model is an excellent model to use as a guiding model for designing motivational elements into a course. This was especially valid and useful when using motivational elements at each stage of the ADDIE design process, as this could be used as a check to add attention, relevance, confidence, and volition driving activities and content to the Course Development Framework. Through this research it was discovered that Bloom's taxonomy was useful in guiding learning outcomes, as academics used Bloom's quite extensively when developing courses and often used, perhaps mistakenly, as an instructional design model.

A Course Development Framework was developed by discovering what learning theories were useful, as well as which models and methods could be used. The Framework combined the ARCS-V motivational model and Blooms taxonomy with the ADDIE model to develop a Framework that can guide academics when creating a course for emerging technologies.

Future research could be conducted in the effectiveness of using the Course Development Framework to test other courses on emerging technologies.

Research in the field of Brain Compatible Learning Principles and combining or using it with the Course Development Framework could provide further insights into advancements in course design and development. 


\section{REFERENCES}

Abachi, H. R., \& Muhammad, G. (2014). The impact of m-learning technology on students and educators. Computers in Human Behavior, 30, 491-496. https://doi.org/10.1016/j.chb.2013.06.018

Agarwal, P. K. (2019). Retrieval practice \& Bloom's taxonomy: Do students need fact knowledge before higher order learning? Journal of Educational Psychology, 111(2), 189-209. https://doi.org/10.1037/edu0000282

Alnajdi, S. M. (2018). The effectiveness of designing and using a practical interactive lesson based on ADDIE model to enhance students' learning performances in University of Tabuk. Journal of Education and Learning, 7(6), 212. https://doi.org/10.5539/jel.v7n6p212

Amineh, R., \& Asl, H. (2015). Review of constructivism and social constructivism. Journal of Social Sciences, Literature and Languages, 1(1), 9-16.

Arghode, V., Brieger, E. W., \& McLean, G. N. (2017). Adult learning theories: Implications for online instruction. European Journal of Training and Development, 41(7), 593-609. https://doi.org/10.1108/EJTD-02-2017$\underline{0014}$

Bair, R. A., \& Stafford, T. (2016). Connected and ubiquitous: A discussion of two theories that impact future learning applications. TechTrends, 60(2), 129-135. https://doi.org/10.1007/s11528-016-0021-z

Ben-Daya, M., Hassini, E., \& Bahroun, Z. (2017). Internet of things and supply chain management:A literature review. International Journal of Production Research, 57(15-16), 4719-4742. https://doi.org/10.1080/00207543.2017.1402140

Benham, H., Carvalho, G., \& Cassens, M. (2014). Student perceptions on the impact of mobile technology in the classroom. Issues in Information Systems, 15(2), 141-150.

Bertucio, B. (2017). The Cartesian heritage of Bloom's Taxonomy. Studies in Philosophy and Education, 36(4), 477497. https://doi.org/10.1007/s11217-017-9575-2

Brereton, P., Kitchenham, B. A., Budgen, D., Turner, M., \& Khalil, M. (2007). Lessons from applying the systematic literature review process within the software engineering domain. Journal of Systems and Software, 80(4), 571-583. https://doi.org/10.1016/j.jss.2006.07.009

Budoya, C. M., Kissake, M. M., \& Mtebe, J. S. (2019). Instructional design enabled Agile Method using ADDIE Model and Feature Driven Development method. International Journal of Education and Development Using Information and Communication Technology (IJEDICT), 15(1), 35-54.

Cheung, L. (2016). Using the ADDIE Model of Instructional Design to teach chest radiograph interpretation. Journal of Biomedical Education, 2016, 1-6. https://doi.org/10.1155/2016/9502572

Chu, Y. (2017). Instructional design of online pre-class tasks of the flipped classroom on the basis of ARCS Model. Proceedings of the 3rd International Conference on Social Science and Management (ICSSM 2017), 88-90. https://doi.org/10.12783/dtssehs/icssm2017/10310

Clarke, V., \& Braun, V. (2013). Teaching thematic analysis: Overcoming challenges and developing strategies for effective learning. The Psychologist, 26(2), 120-123.

Constancio, F. G., Couras, M. F. K., B., Nogueira, D., da Costa, J. P. C. L., Zanatta, M. D. R., de Sousa, R. T., Gomes, F. S., \& da Mota, N. T. (2018). Extended ADDIE Model for improved distance learning courses. 2018 IEEE Frontiers in Education Conference (FIE), 2018-Octob(1), 1-5. https://doi.org/10.1109/FIE.2018.8658925

Czerkawski, B. C., \& Lyman, E. W. (2016). An instructional design framework for fostering student engagement in online learning environments. TechTrends, 60(6), 532-539. https://doi.org/10.1007/s11528-016$\underline{0110-Z}$

Davis, J. (2019). Adult learning with education. http://juliandavis.com/usmx-ldt100x/learning-theory-chart/

Du Boulay, B., \& Del Soldato, T. (2016). Implementation of motivational tactics in tutoring systems: 20 years on. International Journal of Artificial Intelligence in Education, 26(1), 170-182. https://doi.org/10.1007/s40593$\underline{015-0052-1}$ 
van Wyk, Johnston, Möller, \& Haas

Dumford, A. D., \& Miller, A. L. (2018). Online learning in higher education: Exploring advantages and disadvantages for engagement. Journal of Computing in Higher Education, 30(3), 452-465. https://doi.org/10.1007/s12528-018-9179-z

Eachempati, P., Kiran Kumar, K.S., \& Sumanth, K.N. (2016). Blended learning for reinforcing den-tal pharmacology in the clinical years: A qualitative analysis. Indian Journal of Pharmacology, 48(7), 25-28. https://doi.org/10.4103/0253-7613.193315

Fastiggi, W. (2019). Applying Bloom's Taxonomy to the classroom. Technology for Learners. https://technologyforlearners.com/applying-blooms-taxonomy-to-the-classroom/

Ghani, M, T, A., \& Daud, W. A. A. W. (2018). Adaptation of Addie Instructional Model in developing educational website for language. Global Journal of Al-Thafaqaf, 8(2), 7-16.

Goldie, J. G. S. (2016). Connectivism: A knowledge learning theory for the digital age? Medical Teacher, 38(10), 1064-1069. https://doi.org/10.3109/0142159X.2016.1173661

Harasim, L. (2012). Learning theory and online technologies. $1^{\text {st }}$ edition. Routledge, New York. https://doi.org/10.4324/9780203846933

Harasim, L. (2017). Learning Theory and Online Technologies. $2^{\text {nd }}$ edition. Routledge, New York. https://doi.org/10.4324/9781315716831

Hattie, J. (2015). The applicability of Visible Learning to higher education. Scholarship of Teaching and Learning in Psychology, 1(1), 79-91. https://doi.org/10.1037/stl0000021

Hess, A. K. N., \& Greer, K. (2016). Designing for engagement: Using the ADDIE model to integrate highimpact practices into an online information literacy course. Communications in Information Literacy, 10(2), 264-282. https://doi.org/10.15760/comminfolit.2016.10.2.27

Hong-Ning D., Zibin Z., \& Yan Z. (2019). Blockchain for Internet of Things: A Survey. IEEE Internet of Things Journal, 6(5), 8076-8094. https://doi.org/10.1109/jiot.2019.2920987

Hood Cattaneo, K. (2017). Telling active learning pedagogies apart: From theory to practice. Journal of New Approaches in Educational Research, 6(2), 144-152. https://doi.org/10.7821/naer.2017.7.237

Horvitz, B. S., Beach, A. L., Anderson, M. L., \& Xia, J. (2015). Examination of faculty self-efficacy related to online teaching. Innovative Higher Education, 40(4), 305-316. https://doi.org/10.1007/s10755-014-9316-1

Hung, M. (2017). Leading the IoT - Gartner insights on how to lead in a connected world. Gartner. https://www.gartner.com/imagesrv/books/iot/iotEbook digital.pdf

Illeris, K. (2018). An overview of the history of learning theory. European Journal of Education, 53(1), 86-101. https://doi.org/10.1111/ejed.12265

Jiang, Y. (2019). The effective application of fragmented learning guided by constructivism. International Journal of Education, Culture and Society, 3(1), 10. https://doi.org/10.11648/i.ijecs.20180301.13

Johnston, E., Olivas, G., Steele, P., Smith, C., \& Bailey, L. (2018). Exploring pedagogical foundations of existing virtual reality educational applications: A content analysis study. Journal of Educational Technology Systems, 46(4), 414-439. https://doi.org/10.1177/0047239517745560

Johnston, K. A. (2016). The use, impact, and unintended consequences of mobile web-enabled devices in university classrooms. Issues in Informing Science and Information Technology, 13, 25-46.

https://doi.org/10.28945/3464

Jung, H., Kim, Y., Lee, H., \& Shin, Y. (2018). Advanced instructional design for successive e-learning: Based on the Successive Approximation Model (SAM). International Journal on E-Learning, 18(2), 191-204

Juvova, A., Chudy, S., Neumeister, P., Plischke, J., \& Kvintova, J. (2015). Reflection of constructivist theories in current educational practice. Universal Journal of Educational Research, 3(5), 345-349.

https://doi.org/10.13189/ujer.2015.030506

Keller, J. M. (2010). Motivational design for learning and performance: The ARCS Model approach. Springer. https://doi.org/10.1007/978-1-4419-1250-3 
Keller, J. M. (2016). Motivation, learning, and technology: Applying the ARCS-V Motivation Model. Participatory Educational Research, 3(2), 1-15. https://doi.org/10.17275/per.16.06.3.2

Khalil, M. K., \& Elkhider, I. A. (2016). Applying learning theories and instructional design models for effective instruction. Advances in Physiology Education, 40(2), 147-156. https://doi.org/10.1152/advan.00138.2015

Khan, T., Johnston, K., \& Ophoff, J. (2019). The impact of an augmented reality application on learning motivation of students. Advances in Human-Computer Interaction, 2019, 1-14. https://doi.org/10.1155/2019/7208494

Kizilcec, R. F., Pérez-Sanagustín, M., \& Maldonado, J. J. (2017). Self-regulated learning strategies predict learner behavior and goal attainment in Massive Open Online Courses. Computers \& Education, 104, 18-33. https://doi.org/10.1016/j.compedu.2016.10.001

Kizito, R. (2016). Connectivism in learning activity design: Implications for pedagogically-based technology adoption in African higher education contexts. International Review of Research in Open and Distance Learning, 17(2). https://doi.org/10.19173/irrodl.v17i2.2217

Kumi-Yeboah, A. (2018). Designing cross-cultural collaborative online learning framework for online instructors. Online Learning, 22(4), 181-201. https://doi.org/10.24059/olj.v22i4.1520

Li, K., \& Keller, J. M. (2018). Use of the ARCS model in education: A literature review. Computers and Education, 122, 54-62. https://doi.org/10.1016/j.compedu.2018.03.019

Liagkou, V., Salmas, D., \& Stylios, C. (2019). Realizing virtual reality learning environment for industry 4.0. Procedia CIRP, 79, 712-717. https://doi.org/10.1016/j.procir.2019.02.025

Libao, N. J. P, Sagun, J. J. B., Tamangan, E. A., Pattalitan, A. P., Dupa, M. E. D, \& Bautista, R. G. (2016). Science learning motivation as correlate of students' academic performances. Journal of Technology and Science Education, 6(3), 209. https://doi.org/10.3926/jotse.231

Loorbach, N., Peters, O., Karreman, J., \& Steehouder, M. (2015). Validation of the Instructional Materials Motivation Survey (IMMS) in a self-directed instructional setting aimed at working with technology. British Journal of Educational Technology, 46(1), 204-218. https://doi.org/10.1111/bjet.12138

Macaulay, J., Buckalew, L., \& Chung, G. (2015). Internet of Things in logistics. DHL Trend Research/Cisco Consulting Services.

McCaffrey, M. (2017). Unreal Engine VR Cookbook: Developing virtual reality with UE4 (1st ed.). Addison-Wesley Professional PTG.

Meier, D. (2016). Situational leadership theory as a foundation for a blended learning framework. Jounrnal of Education and Practice, 7(10), 25-30.

Nadiyah, R. S., \& Faaizah, S. (2015). The development of online project based collaborative learning using ADDIE Model. Procedia - Social and Behavioral Sciences, 195, 1803-1812. https://doi.org/10.1016/j.sbspro.2015.06.392

Panetta, K. (2018). Gartner Top 10 strategic technology trends for 2019. Gartner. https://www.gartner.com/smarterwithgartner/gartner-top-10-strategic-technology-trends-for-2019/

Rahman, S. A., \& Manaf, N. F. A. (2017). A critical analysis of Bloom's Taxonomy in teaching creative and critical thinking skills in Malaysia through English literature. English Language Teaching, 10(9), 245. https://doi.org/10.5539/elt.v10n9p245

Reese, S. A. (2015). Online learning environments in higher education: Connectivism vs. dissociation. Education and Information Technologies, 20(3), 579-588. https://doi.org/10.1007/s10639-013-9303-7

Robinson, J. M. (2018). Evaluation of teaching methods to improve reading performance of English language learners. Journal for the Advancement of Educational Research International, 12, 25-33.

Saari, A. (2019). Out of the box: Behaviourism and the mangle of practice. Discourse: Studies in the Cultural Politics of Education, 40(1), 109-121. https://doi.org/10.1080/01596306.2018.1549707

Sahin, M., \& Dogantay, H. (2018). Critical Thinking and Transformative Learning. Journal of Innovation in Psychology, Education and Didactics, 22(1), 103-114. https://eric.ed.gov/?id=ED593584 
van Wyk, Johnston, Möller, \& Haas

Saunders, M. N. K., Lewis, P., \& Thornhill, A. (2019). Research methods for business students (8th ed.). Pearson.

Scoppio, G., \& Luyt, I. (2017). Mind the gap: Enabling online faculty and instructional designers in mapping new models for quality online courses. Education and Information Technologies, 22(3), 725-746. https://doi.org/10.1007/s10639-015-9452-y

Shahril, M. I. B, Salimin, N. B., \& a/l Elumalai, G. (2015). The validity and reliability of ISO test towards the performance assessment of future physical education teachers in teaching and learning process. Social and Behavioral Sciences, 195( 2015), 814 - 820. https://doi.org/10.1016/j.sbspro.2015.06.184

Stanny, C. (2016). Reevaluating Bloom's Taxonomy: What measurable verbs can and cannot say about student learning. Education Sciences, 6(4), 37. https://doi.org/10.3390/educsci6040037

Tan, C. (2017). Constructivism and pedagogical reform in China: Issues and challenges. Globalisation, Societies and Education, 15(2), 238-247. https://doi.org/10.1080/14767724.2015.1105737

Tervonen, J.K., Hautamäki, J., Heikkilä, M., \& Isoherranen, V. (2018). Survey of business excellence by knowledge gathering for industrial internet-of-things applications. International Journal of Management and Enterprise Development, 17(4), 388-410. https://doi.org/10.1504/ijmed.2018.10017528

Trust, T., \& Pektas, E. (2018). Using the ADDIE Model and Universal Design for Learning Principles to develop an open online course for teacher professional development. Journal of Digital Learning in Teacher Education, 34(4), 219-233. https://doi.org/10.1080/21532974.2018.1494521

Ucar, H., \& Kumtepe, A. T. (2016, March). Use of ARCS-V motivational design model in online distance education. In G. Chamblee \& L. Langub (Eds.), Proceedings of the Society for Information Tecbnology \& Teacher Education International Conference (pp. 55-60). Association for the Advancement of Computing in Education (AACE).

Usher, W., Edwards, A., \& de Meyrick, B. (2015). Utilizing educational theoretical models to support effective physical education pedagogy. Cogent Education, 2(1). https://doi.org/10.1080/2331186X.2015.1094847

van Niekerk, J., \& Webb, P. (2016). The effectiveness of brain-compatible blended learning material in the teaching of programming logic. Computers and Education, 103, 16-27.

https://doi.org/10.1016/j.compedu.2016.09.008

van Wyk, N. (2019). A proposed framework for developing online courses: The case for a VR course. (Unpublished Thesis for a BCom (Honours) at University of Cape Town, South Africa).

Veletsianos, G. (Ed.). (2016). Emergence and innovation in digital learning. AU Press. http://www.giseldacosta.com/wordpress/wp-content/uploads/2016/08/Veletsianos.pdf

Witkowski, K. (2017). Internet of Things, Big Data, Industry 4.0 - Innovative solutions in logistics and supply chains management. Procedia Engineering, 182, 763-769. https://doi.org/10.1016/i.proeng.2017.03.197

Yan, K. (2017). A comparison between two leading linguistic figures: Bloomfield and Firth. Proceedings of the 2017 International Conference on Management, Education and Social Science (ICMESS 2017), 461-464. https://doi.org/10.2991/icmess-17.2017.108

Yarbrough, J. R. (2018). Adapting adult learning theory to support innovative, advanced, online learningWVMD Model. Research in Higher Education Journal, 35, 1-15.

Yilmaz, T. K., \& Cagiltay, K. (2016). Designing and developing game-like learning experience in virtual worlds: Challenges and design decisions of novice instructional designers. Contemporary Educational Technology, 7(3), 206-222. https://doi.org/10.30935/cedtech/6173

Yumurtaci, O. (2017). A re-evaluation of mobile communication technology: A theoretical approach for technology evaluation in contemporary digital learning. Turkish Online Journal of Distance Education, 18(1), 213 223. https://doi.org/10.17718/tojde. 285817 


\section{BIOGRAPHIES}

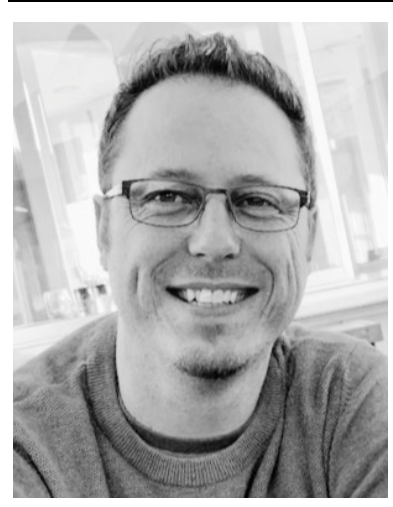

Norman van Wyk is an online teacher at Noroff University, Norway. Norman has worked in a variety of multi-disciplinary fields which allowed him to combine his knowledge in digital learning, instructional design, cyber security and interactive multimedia in a multitude of projects and environments. Norman is actively involved in education, virtual reality, serious games and information technology. Online education and research is a passion of his and he would love to see online learning technology open doors to a brighter future for many, no matter where they are in the world.

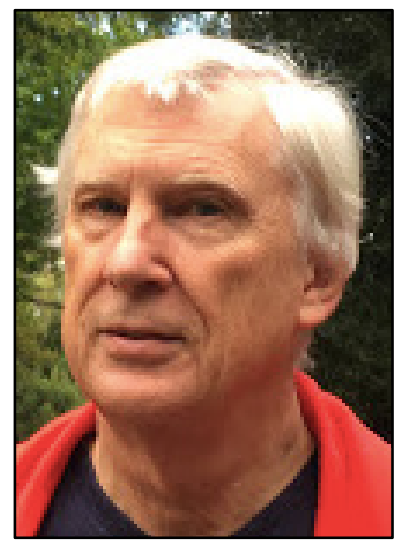

Kevin Johnston is an Emeritus Professor and former Head of Department of the Department of Information Systems at the University of Cape Town, South Africa, and a visiting Professor at the University of Pforzheim, Germany. His principal research areas are ICT strategy and management, IS educational issues, Social and Networking systems, Emerging technology, and Entrepreneurship.

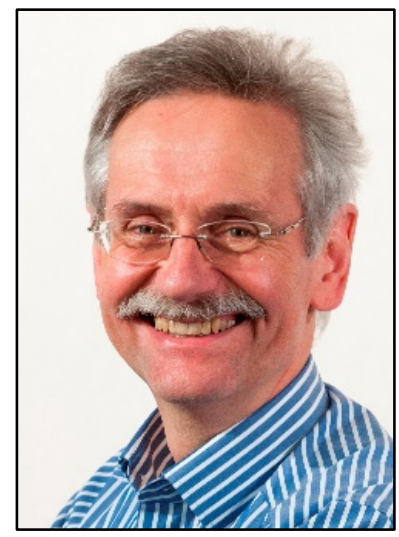

Dr.-Ing. Klaus Möller is Professor for Distribution Logistics in the Business School at Pforzheim University, Germany. He has 20 years of teaching experience in higher education in international universities and is actively conducting research in Supply Chain Management and Applied Information Systems in Logistics, in particular in Warehouse Management Systems. 


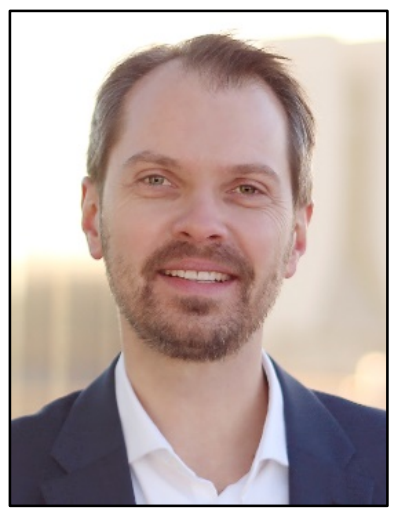

Dr. Florian Haas is Professor for Purchasing and Supply Management at the Business School of Pforzheim University, Germany. He has more than 15 years of experience in Supply Chain Management. Amongst others he was responsible for the implementation of a central sea and air freight transport management at Bosch and cooperated with ocean carriers to pilot the application of blockchain technology for sea freight transports. 